\title{
EDUCACIÓN Y CIUDADANÍA PLANETARIA. CONCEPCIONES DEL ALUMNADO PARTICIPANTE EN PROGRAMAS EDUCATIVOS ANDALUCES
}

\author{
EDUCATION AND PLANETARYCITIZENSHIP. \\ CONCEPTIONS OF THESTUDENTSPARTICIPANTS IN EDUCATIONAL \\ ANDALUSIAN PROGRAMS
}

\section{PLANETARY EDUCAÇÃO PARA A CIDADANIA. CONCEPÇÃO DOS ESTUDANTES QUE PARTICIPAM EM PROGRAMAS EDUCACIONAIS ANDALUZES}

\section{Olga Moreno Fernández}

UnIVERSIDAD DE SEVILLA, ESPAÑA

RESUMEN: Sociedad y Educación parecen estar estrechando lazos en las últimas décadas debido a diversos factores sociales que están cambiando en la actualidad en el orden mundial, surgiendo así nuevos planteamientos educativos para este siglo XXI. Unos cambios que nos hacen reflexionar acerca de la necesidad de abordar una ciudadanía no centrada en lo local, sino abordando un espectro más amplio, conformando una ciudadanía planetaria crítica, participativa, dialogante, holística y equitativa donde cada persona juegue un papel fundamental y relevante. Esta ciudadanía planetaria debe ser abordada desde la escuela con la intención de que se produzcan cambios perceptibles en el tejido social. Conclusiones que nos llevarán a plantearnos la necesidad de una educación para una "ciudadanía global" o "ciudadanía planetaria" como un reto a abordar. Esta investigación pretende aportar información e ideas sobre la importancia que los programas educativos que fomentan la participación ciudadana tienen en nuestro alumnado para promover las competencias derivadas de la ciudadanía activa. Por otra parte, constituye una primera aproximación a algunos de los programas educativos ofertados desde distintas administraciones públicas andaluzas y que se incorporan al contexto educativo en horario escolar. En concreto, se presentan los resultados obtenidos para los programas educativos "Ecoescuela", "Parlamento Joven" " "Seguro que te mueves", desde el punto de vista del alumnado. Como objetivos nos planteamos detectar las concepciones de la muestra seleccionada con respecto a los temas de estudio que nos ocupan, así como verificar si la educación para la ciudadanía planetaria está presente en estos programas. La recogida de datos, que tiene su enfoque en una metodología cualitativa, se ha llevado a cabo a partir de cuestionario de preguntas abiertas, entrevistas semi-estructuradas, y grupos de discusión. Datos que posteriormente han sido tratados con

EDUCACIÓN Y CIUDADANÍA PLANETARIA. CONCEPCIONES DEL ALUMNADO PARTICIPANTE EN PROGRAMAS EDUCATIVOS ANDALUCES [ 229 ] 
el software de análisis Atlas.ti (versión 6.2). Su tratamiento y análisis han concretado cómo estos programas educativos favorecen la participación del alumnado en sus vidas cotidianas y en la comunidad donde viven, así como la visión de "ciudadanía planetaria" que tienen y su capacidad para relacionar cuestiones relevantes locales con problemas globales. Y es que, la educación ciudadana planetaria se traduce en dar una visión de polis mundial desde la escuela, la comunidad, los Estados, etc. Una visión de polis mundial donde todos los seres humanos, independientemente del lugar del mundo donde se encuentren, se sientan parte de un mismo pueblo; y con un misma finalidad, la de participar de forma activa y responsable en las decisiones que afectan a nuestro planeta.

PALABRAS CLAVE: Educación Ambiental; Educación Ciudadana; Ciudadanía Planetaria; Programas educativos.

ABSTRACT: Society and Education seem closer ties in recent decades due to various social factors that are now changing the world order and the emerging new educational approaches for this century. Changes that make us reflect on the need to address citizenship not center don the local, but addressing a broader spectrum, forming a planetary citizenship review relevant, participatory, dialogical, holistic and equitable where every living being and play a key role. This planetary citizenship must be approached from the school with the intention that perceptible changes in the social fabric. Conclusions lead us to consider the need for education for a "global citizenship" or "global citizenship" as a challenge to address. This research aims to provide information and ideas on the importance of educational programs that promote citizen participation in our students have the skills to promote active citizenship derived. On the other hand, is a first approach to some of the educational programs offered from different Andalusian (Spain) government and incorporated into the educational context in school. The results for educational programs "Eco-School", "Youth Parliament" and "Sure you move" from the point of view of the student presents particular. As we set goals detecting conceptions of the sample with respect to the study topics that concern us as well as check if education for planetary citizenship is present in these programs. Data collection, which has its focus on a qualitative methodology, was carried out from open-ended questionnaire, semi-structured interviews and focus groups. Data were subsequently treated with analysis software Atlas.ti (version 6.2). Processing and analysis have finalized how these educational programs encourage student participation in their daily lives and in the community where they live, and the vision of "planetary citizenship" they have and their ability to relate local issues relevant to global problems. And is that the planetary citizenship education translates into giving a global view of cops from the school, the community, States, A vision of global polis where all human beings, regardless of where in the world are part of the same peoples it; and a same purpose, to participate actively and responsibly in the decisions that affect our planet.

KEYWORDS: Environmental Education; Citizenship Education; PlanetaryCitizenship; Education Programs.

RESUMO: Sociedade e Educação parecem laços mais estreitos nas últimas décadas devido a vários fatores sociais que estão a mudar a ordem do mundo, que dão origem a novas abordagens educacionais para este século. Alterações que nos fazem refletir sobre a necessidade de abordar a cidadania não centrada no local, mas que abordam um espectro mais amplo, formando uma cidadania planetária crítico, participativo, dialógico, holística e equitativa onde cada personajuegue um papel fundamental e importante.

Esta cidadania planetária deve ser abordada a partir da escola com a intenção de que mudanças visíveis no tecido social. Conclusões que vai nos levar a considerar a necessidade de uma educação para uma "cidadania global" ou "cidadania global" como um desafio a enfrentar. Esta pesquisa tem como objetivo fornecer informações e idéias sobre a importância de programas educacionais que incentivam a participação dos cidadãos nos nossos alunos têm as habilidades de promover a cidadania derivada. Por outro lado, é uma primeira abordagem a alguns dos programas educacionais oferecidos a partir de diferentes governos andalu-

[ 230 ] OLGA MORENO FERNÁNDEZ

SIPS - PEDAGOGIA SOCIAL. REVISTA INTERUNIVERSITARIA [1139-1723 (2015) 26, 229-261] TERCERA ÉPOCA 
zes e incorporados no contexto educacional na escola. Especificamente, os resultados para "Ecoescuela", "Parlamento dos Jovens" e "Claro que você se mover" programas educacionais são apresentados, a partir do ponto de vista do aluno. Como estabelecemos metas detectar as concepções da amostra selecionada para os temas de estudo que nos preocupam, e verificar se a educação para a cidadania global está presente nestes programas. A coleta de dados, que tem seu foco na metodologia qualitativa foi realizada a partir de questionário aberto, entrevistas semi-estruturadas e grupos focais. Os dados foram posteriormente tratados com o software de análise Atlas.ti (versão 6.2). Processamento e análise se materializaram como esses programas educacionais incentivar a participação dos estudantes em suas vidas diárias e na comunidade onde vivem, bem como a visão de "cidadania global" que eles têm e sua capacidade de se relacionar questões locais relevantes para problemas globais. E é que, educação para a cidadania planetária se traduz em dar uma visão da polis global a partir da escola, a comunidade, os Estados, etc. A visão da polis globais onde todos os seres humanos, independentemente de onde no mundo fazem parte das mesmas pessoas se sentar; e um mesmo propósito, para participar ativa e responsavelmente nas decisões que afetam nosso planeta.

PALAVRAS-CHAVE: Educação Ambiental; Educação para a cidadania; Cidadania Planetária; Programas educacionais.

\section{Introducción}

Este artículo es resultado de una investigación de corte cualitativo realizada en el marco de algunos de los programas educativos ("Ecoescuela", "Parlamento Joven" " "Seguro que te mueves") que trabajan temáticas relacionadas con la educación ambiental y/o la educación para la ciudadanía en Andalucía. A través del estudio de estos programas se pretende demostrar que ambos ejes o temas transversales en el currículo escolar (educación ambiental y educación para la ciudadanía), dado que comparten finalidades educativas similares, se pueden complementar, de forma que se aborde un contenido más coherente, realista y útil fundamentado en una perspectiva de educación ciudadana planetaria.

El objetivo principal de la investigación es analizar las concepciones que tiene el alumnado acerca del programa educativo en el que participa, así como conocer si a través del mismo se ofrece un enfoque ciudadano planetario en el que medio ambiente y ciudadanía forman parte de un mismo plano

Sin posibilidad de presentar aquí exhaustivamente con detalle los resultados de la investigación, se describen brevemente los programas estudiados, para a continuación presentar los resultados más relevantes obtenidos en relación a las concepciones del alumnado implicado.

\section{Introduction}

This article is the result of a qualitative research conducted in the context of some of the ('EcoSchool', 'Youth Parliament' and 'Sure you move') educational programs working issues related to environmental education and / or education for citizenship in Andalucía (Spain). Through the study of these programs is to show that either axes or cross-cutting themes in the school curriculum (environmental education and education for citizenship) because they share similar educational purposes, can be supplemented so that a more coherent content is addressed, realistic and useful perspective based on a planetary citizenship education.

The main objective of the research is to analyze the conceptions held by students about the educational program in which participates, and to know if there through is offered a planetary citizen approach in which environmental and citizenship are part of the same plane.

No opportunity to present here exhaustively detailed results of the research are briefly described the programs studied, for then present the main results obtained in relation to the conceptions of students involved.

The interest of this research arises from the increasingly theoretical studies being made about 
El interés de la presente investigación surge de los cada vez más estudios teóricos que se están realizando acerca de la necesidad de formar ciudadanos planetarios, sensibilizados con las cuestiones relevantes de nuestro mundo y a las implicaciones sociales que genera la globalización en las prácticas ciudadanas del siglo XXI (Bonal, Tarabino-Castellani y Verger, 2007; Cabrera, 2002; Cortina, 2003; Dias y Bonotto, 2012; Gutiérrez y Prado, 1995; Mayer, 2002; Novo y Murga, 2010; Santos, 2002; Wilbanks y Kates, 1999) y la escasez de estudios empíricos que aborden el tema desde el ámbito educativo en general, $y$ desde el alumnado en particular, donde enmarcamos nuestra contribución.

\section{Ciudadanía Planetaria y educación}

Cuando se hace referencia a la ciudadanía planetaria pueden utilizarse distintas denominaciones, lo que puede llegar a plantear confusiones, ya que en función de la denominación que utilicemos, el término puede presentar variaciones ideológicas. Algunas de las denominaciones que encontramos para referirnos a esta concepción de la ciudadanía son ciudadanía planetaria (Boff,1995; Gutiérrez Pérez, 2003), ciudadanía global (Banks, 1997; Olu, 1997; Merryfield, Jarchow y Pickert, 1997), ciudadanía universal (UNESCO), ciudadanía mundial (Carta de las Naciones Unidas, 1945; Pasquino, 2001), ciudadanía cosmopolita (Nussbaum, 1999; Cortina, 2003), ciudadanía responsable (Consejo de Europa, 1988,1999; Bell, 1991; Spencer y Klug, 1998),ciudadanía activa (Osler, 1998, 2000; Bárcena, 1997), ciudadanía crítica (Giroux, 1993; Mayordomo, 1998; Inglehart, 1996), ciudadanía intercultural (Cortina, 1990), ciudadanía multicultural (Kymlicka, 1995; Carneiro, 1996), ciudadanía diferenciada (Joung, 1990), ciudadanía paritaria (Carneiro, 1990), ciudadanía democrática y social (Carneiro, 1999), ciudadanía ambiental o ciudadanía ecológica (Carneiro, 1996; Van Steenbergen, 1994; Dobson, 2001, 2005).

Una ciudadanía planetaria que bebe de las bases de lo que se ha llamado quinta generación de la Educación para el Desarrollo, y que comienza a formarse un hueco en el panorama social europeo en torno a los años 40 a través de organizaciones sin ánimo de lucro, instituciones religiosas, y diferentes movimientos sociales con el objetivo de generar en the need to form planetary citizens, sensitized with the relevant issues in our world and the social implications generated by globalization in the twenty-first century citizenship practices (Bonal, Tarabino-Castellani \& Verger, 2007; Cabrera, 2002; Cortina, 2003; Dias \& Bonotto, 2012; Gutiérrez \& Prado, 1995; Mayer, 2002; Novo \& Murga, 2010; Santos, 2002; Wilbanks \& Kates, 1999) and the scarcity of empirical studies that address the issue from the field of education in general, and from the students in particular, where we frame our contribution.

\section{Planetary citizenship and education}

For referring to global citizenship can be used different denominations which can pose confusion, since according to the name we use, the term may have ideological variations. Some of the names found to refer to this conception of citizenship are planetary citizenship (Boff, 1995; Gutiérrez Pérez, 2003), global citizenship (Banks, 1997; Olu, 1997; Merryfield, Jarchow \& Pickert, 1997), universal citizenship (UNESCO), world citizenship (Carta de las Naciones Unidas, 1945; Pasquino, 2001), cosmopolitan citizenship (Nussbaum, 1999; Cortina, 2003), responsible citizenship (Consejo de Europa, 1988,1999; Bell, 1991; Spencer \& Klug, 1998), active citizenship (Osler, 1998, 2000; Bárcena, 1997), critical citizenship (Giroux, 1993; Mayordomo, 1998; Inglehart, 1996), intercultural citizenship (Cortina, 1990), multicultural citizenship (Kymlicka, 1995; Carneiro, 1996), differentiated citizenship (Joung, 1990), equal citizenship (Carneiro, 1990), democratic and social citizenship (Carneiro, 1999), environmental citizenship or ecological citizenship (Carneiro, 1996; Van Steenbergen, 1994; Dobson, 2001, 2005).

A planetary citizenship that draws on the basis of what has been called fifth generation of Development Education and begins to form a gap in the European social landscape around the 4Os through nonprofit organizations, religious institutions and various social movements in order to generate citizenship a critical awareness of the global reality, so that tools to facilitate participa- 
la ciudadanía una conciencia crítica sobre la realidad mundial, de forma que se faciliten herramientas para la participación en la sociedad y que la transformación social sea una realidad (Moreno Fernández, Moreno Crespo y Martín, 2011).

Un concepto, el de ciudadanía global que está cada vez más presente dentro del ámbito educativo. Aunque este es el término más utilizado, nos hemos decantado por el uso de ciudadanía planetaria debido a la ambigüedad que encierra de por sí el término global, ya que en ocasiones, puede dar lugar a confusiones que remitan a crear un binomio ciudadanía global/ globalización. Por lo tanto, consideramos que "el concepto de ciudadanía global estaría mucho más ligado al reciente proceso de globalización provocado por los avances tecnológicos; en cuanto a la planetariedad, continua siendo un deseo, un sueño que viene de mucho más lejos"(Gadotti et al; 2003, p. 100).

Desde la Organización de las Naciones Unidas para la Educación, la Ciencia y la Cultura (UNESCO) se ha promovido activamente la idea de la educación para la ciudadanía planetaria a través del Decenio de las Naciones Unidas para la Educación en el ámbito de los Derechos Humanos (1995-2004). Asimismo, los Planes Directores de Cooperación Española 2005-2008 y 2009-2012, hacen mención a la educación como un factor imprescindible para promover una educación ciudadana planetaria. Así el Plan Director de la Cooperación Española 20052008 (2005, pp.140-141) se refiere a la Educación para el Desarrollo como un:

[...] proceso educativo constante que favorece la comprensión de las interrelaciones económicas, políticas, sociales y culturales entre el Norte y el Sur; promueve valores y actitudes relacionadas con la solidaridad y la justicia social y busca vías de acción para lograr un desarrollo humano y sostenible. Es una educación sociopolítica, cuyo eje es la justicia social que se lleva a cabo en los ámbitos educativos formales y no formales.

Esta forma de entender la educación comienza a generarse un espacio con entidad propia en el panorama social europeo a través de organizaciones sin ánimo de lucro, instituciones religiosas, y diferentes movimientos sociales, con el objetivo de generar en la ciudadanía una conciencia crítica sobre tion in society and social transformation a reality (Moreno-Fernández, Moreno-Crespo \& MartínBermúdez, 2011).

A concept, global citizenship is increasingly present in the educational field. Although this is the term most commonly used, we opted for the use of planetary citizenship due to the ambiguity that encloses in it the global term, because sometimes it can be confusing to remit to create a binomial global citizenship / globalization. Therefore, we believe that the concept of global citizenship would be more linked to the recent globalization process caused by technological advances, in terms of the planetary citizenship; remains a desire, a dream come much further (Gadotti \& others; 2003, p. 100).

From the United Nations Educational, Scientific and Cultural Organization (UNESCO) has actively promoted the idea of education for global citizenship through the United Nations Decade for Education in the field of Human Rights (1995-2004). Also, the Spanish Cooperation Master Plans 2005-2008 and 2009-2012, mention education as an essential factor to promote planetary citizenship education. The Director Plan of the Spanish Cooperation 2005-2008 (2005, pp.140-141) refers to the Education for Development as a:

[...] a constant process educational that promotes understanding of the economic, political, social and cultural interrelations between North and South; promotes values and attitudes related to solidarity and social justice and seeks ways of action to achieve sustainable human development. It is a socio-political education, whose axis is social justice that takes place in formal and non-formal educational settings.

As mentioned above, this way of understanding education begins to generate a space with its own identity in the European social landscape through nonprofit organizations, religious institutions, and various social movements, in order to generate awareness among citizens criticism of the global reality, so that tools to facilitate participation in society and social transformation a reality (Moreno-Fernández, Moreno-Crespo \& Martín-Bermúdez, 2011). 
la realidad mundial, de forma que se faciliten herramientas para la participación en la sociedad y que la transformación social sea una realidad(Moreno Fernández, Moreno Crespo y Martín Bermúdez, 2011).

Los Informes Eurydice de Educación para la Ciudadanía (2005, 2012), que ofrecen una panorámica actual sobre cómo se aborda la educación ciudadana en el contexto escolar europeo, también incorporan la educación para una ciudadanía planetaria como un contenido imprescindible dentro de los currículos educativos. Países como Eslovaquia, Reino Unido, Bulgaria, entre otros, hacen alusión a la ciudadanía planetaria o ciudadanía global. Un ejemplo lo podemos ver en Gales, donde la inspección educativa evalúa la planificación de la educación personal y social, así como la comprensión del alumnado relativa al desarrollo sostenible y a la ciudadanía global. El informe Eurydice (2012) hace referencia a España, concretamente señala desde 2009, los Premios Fundación Vicente Ferrer a la Educación para el Desarrollo, seleccionan anualmente los 15 mejores proyectos realizados en las aulas escolares, poniendo el acento en que los seleccionados deben de promover el pensamiento crítico y fomentar la participación activa de los estudiantes en la búsqueda de una ciudadanía global, la solidaridad, la erradicación de la pobreza y el desarrollo sostenible, entre otros valores.

\section{Educación para una ciudadana planetaria en las aulas escolares}

El constante proceso de cambio en el que se encuentra el mundo, y con él las sociedades, está dejando notar los efectos y consecuencias de la globalización en cualquier punto del planeta, abriendo también nuevos retos a la educación. La escuela del siglo veintiuno se incorpora a este nuevo escenario con el reto de ofrecer a sus discentes herramientas válidas para desenvolverse en este nuevo contexto. Herramientas que deben servir para interpretar el mundo donde se vive, en cualquier lugar y a cualquier edad (Moreno Fernández y García Pérez, 2013; Moreno Fernández y Bonotto, 2014).

Frente a estas cuestiones, la escuela cumple un papel fundamental. Esta institución, no sólo forma a personas, sino también a ciudadanos, entendiendo a estos más allá del concepto que hace referencia
The Reports Eurydice of Education for Citizenship (2005, 2012), which provide a current overview of how citizenship education is addressed in School in Europe also incorporate education for planetary citizenship as an essential content in the curricula. Countries such as Slovakia, UK, Bulgaria, among others, allude to planetary citizenship or global citizenship. An example can be seen in Wales, where education inspection evaluates the planning of personal and social education and student understanding on sustainable development and global citizenship. The Report Eurydice (2012) refers to Spain, since 2009, to the Vicente Ferrer Foundation Awards to Education for Development that annually selects the 15 best projects realized in the classrooms, emphasizing the need to promote critical thinking and encourage the active participation of students in the pursuit of global citizenship, solidarity, poverty eradication and sustainable development, among other values.

\section{Education for planetary citizenship in the classroom}

The constant process of change that is the world, and with him societies, is leaving notes the effects and consequences of globalization on anywhere in the world, opening up new challenges to education. The school twenty-first century is incorporated into this new stage with the challenge of offering its learners valid tools to manage in this new context. Tools to be used to interpret the world in which we live, anywhere and at any age (Moreno-Fernández \& García Pérez, 2013; Moreno Fernández \& Bonotto, 2014).

Faced with these issues, the school plays a key role. This institution, not only trains people but also citizens, understanding these beyond the concept that refers to individual living in a local community with a series of rights and duties, and being 
a individuo que vive en una comunidad local con una serie de derechos y deberes, y estando más cerca de un concepto de ciudadanos críticos, capaces de entender y valorar las problemáticas de su mundo, y con capacidad para formar parte de una ciudadanía participativa, flexible y activa políticamente.

Es decir, parte de una ciudadanía planetaria, ya que "la educación puede contribuir a la transformación social, si se vive como un proceso dinámico, que desborda ampliamente los aprendizajes escolares para vincularse a la realidad social y política con una intención claramente transformadora" (Bartolomé, 2000, p. 118).

Coincidimos con Ferrete (2011) en la idea de que una gobernanza global permite ampliar los espacios y los instrumentos fortaleciendo la conciencia y la competencia cívica, aunque sin perder de vista la educación como el factor más importante a la hora de empoderar a la ciudadanía. Una gobernanza global, complementada a escala local, regional, nacional, y global, para la que sería necesario contar con instituciones públicas globales, que estudien y aporten medidas a corto, medio y largo plazo que permitan afrontar las cuestiones relevantes que nos atañen en todos los espacios (políticos, económicos, institucionales, sociales, etc.). Lo que implicaría que la ciudadanía tuviera a su disposición todos aquellos instrumentos necesarios para poder tomar decisiones y proponer iniciativas en todos aquellos ámbitos que fueran de su interés o por lo cuales le concerniera de alguna forma (García Marzà, 1993; Ferrete, 2011).

La escuela, que ocupa un lugar central como base de la socialización de nuestro alumnado, tiene una responsabilidad ineludible (Camps, 2000; Cortina, 1996; De Paz, 2007; Martínez Bonafé, 2003; Martínez Martín, 2011; Naval, 2001) en la educación de la ciudadanía, una educación que debe de abordarse desde unos planteamientos críticos y responsables, que den como resultado una ciudadanía planetaria acorde a las necesidades de las nuevas realidades mundiales, porque como señala Majó (2002, p. 45):

Los ciudadanos de hoy deben aprender que tienen un compromiso muy estrecho con su comunidad más próxima, pero que los problemas de todo el mundo son también sus problemas. Hay que conocer bien las propias raíces, pero hay que tener una clara conciencia de los closer to the concept of critical citizens able to understand and appreciate the problems of the world, and able to be part of a participatory, flexible and politically active citizenship.

That is, part of a planetary citizenship, as the education can contribute to social transformation, if lived as a dynamic process that goes far beyond school learning to be linked to the social and political reality with a clearly transformative intent (Bartolomé, 2000, p. 118).

We agree with Ferrete (2011) on the idea that global governance can expand the space and tools to strengthen awareness and civic competence, but without losing sight of education as the most important factor when citizens empower. A global governance, supplemented at local, regional, national, and global, for that would be needed global public institutions, to study and provide measures in the short, medium and long term that can cope relevant issues that concern us all spaces (political, economic, institutional, social, etc.). Implying that citizens have at their disposal all instruments necessary to make decisions and propose initiatives in all areas that were of interest (García Marzà, 1993; Ferrete, 2011).

The school, which occupies a central place to base the socialization of our students, has an inescapable responsibility for the education of citizens (Camps, 2000; Cortina, 1996; De Paz, 2007; Martínez Bonafé, 2003; Martínez Martín, 2011; Naval, 2001), an education that should be approached from a critical and responsible expositions that result in a planetary citizenship according to the needs of the new global realities, because as Majó (2002, p. 45) indicates:

[...] the citizenship of nowadays need to learn that they have a very narrow commitment to their nearest community, but that the problems around the world are also its problems. It is necessary that we know our roots, but also it is necessary that we have conscience of the world problems. We must not lose the identity, but is no longer possible to live on an island.

And it is in this direction that education, the school and the scenarios of citizen participation must connect, allowing to the citizenship create 
problemas globales. No hay que perder la identidad, pero ha dejado de ser posible vivir en una isla.

Y es en esta dirección que la educación, la escuela y los escenarios de participación ciudadana deben conectarse, permitiendo a la ciudadanía crear nuevos espacios de experiencia individual y colectiva (Márquez, 2010).

Coincidimos con García Pérez y De Alba (2008), en que la idea de ciudadanía en la que nos basamos, no debería de estar sujeta a los límites convencionales de los campos de conocimientos implicados en la enseñanza, permitiendo incorporar un enfoque complejo, aunque por encima de esto, se requiere una educación vinculada a la acción, a la participación, a través de la cual se acerque al alumnado a las problemáticas socio-ambientales de nuestro mundo.

Una ciudadanía planetaria, que como señalan Boni (2011) o Boni, Hoffman y Sow (2012), comienza a incorporarse al ámbito educativo formal, como lo demuestran iniciativas promovidas desde el Development Research Centre en el Reino Unido (Bourn, 2008) o programas educativos ofertados desde diversas Organizaciones No Gubernamentales (ONGs) en España (Proyecto Kaidara de Intermon Oxfam, 2005, 2008; Enrédate de UNICEF, 2005; o InteRed, 2011).

No sólo desde las distintas ONGs se están ofreciendo a los centros educativos experiencias que ponen su enfoque en la adquisición de valores acorde con la ciudadanía planetaria, también, desde distintas instituciones públicas se están ofertando programas educativos, que, aunque no tienen per se un enfoque orientado a la consecución de una ciudadanía planetaria, si fomentan valores intrínsecos a ésta. Es el caso de los programas a estudio, Ecoescuela, Parlamento Joven y Seguro que te mueves.

Aunque estas experiencias son un primer paso hacia la inclusión de una educación ciudadana planetaria en el ámbito educativo formal, no podemos perder de vista que estas iniciativas, promovidas en el contexto internacional y nacional, a pesar de impartirse tanto en horario escolar, como con el profesorado del centro, estando incluso inmersos en algunos casos en asignaturas concretas, se incluyen dentro de la educación no formal, teniendo un carácter voluntario por parte de los centros que de- new spaces of individual experience and collective (Márquez, 2010).

We agree with García Pérez \& De Alba (2008), in which the idea of citizenship in which we rely, should not be subject to the conventional boundaries of the fields of knowledge involved in teaching, allowing incorporate a complex approach, although above this, an education linked to action, participation, through which you approach the students to the socio-environmental problems of our world is required.

A planetary citizenship, as noted Boni (2011) or Boni, Hoffman and Sow (2012), begins to enter the formal education sector, as evidenced by initiatives promoted by the Development Research Centre in the UK (Bourn, 2008) or Programs education offered from various Non Governmental Organizations (NGOs) in Spain (Kaidara Project of Intermon Oxfam, 2005, 2008; Enrédate of UNICEF, 2005; or InteRed, 2011).

Not only from the different NGOs are offering experiences schools who put their focus on the acquisition of values consistent with planetary citizenship, also from various public institutions are offering educational programs, although they have not per se an approach aimed at achieving a planetary citizenship if it foster intrinsic values. This is the case of programs to study, Eco-School, Youth Parliament and Sure you move.

Although these experiences are a first step towards the inclusion of a planetary citizenship education in the formal education sector, we can't forget that these initiatives promoted at international and national context, despite taught both in school hours, as the teaching staff, being immersed in some cases even in specific subjects, are included in non-formal education, having a voluntary basis by the centers wishing to join. It's the case of the educative program Sure you move, linked to the subject of Education for Citizenship and Human Rights.

[ 236 ] OLGA MORENO FERNÁNDEZ 
ciden adherirse. Como sería el caso del programa educativo Seguro que te mueves, programa vinculado a la materia de Educación para la ciudadanía y los Derechos Humanos.

\section{Programas educativos a estudio: Ecoes- cuela, Parlamento Joven y Seguro que te mueves}

Los programas educativos en los que se ha centrado la investigación se enmarcan en los ámbitos de la educación ambiental, la educación ciudadana, la seguridad vial y la participación ciudadana, los cuales presentamos a continuación.

\subsection{Ecoescuela}

En España el programa Ecoescuelas es desarrollado por la Asociación de Educación Ambiental y del Consumidor (ADEAC) junto a la Coordinación de la Foundation for Environmental Education (FEE), estando enfocado a la adquisición de actitudes ciudadanas y de compromiso con el medioambiente a niveles de gestión y de certificación ambiental.

Se pone en marcha en el curso escolar 1998/1999 con 72 centros participantes, número que ha ido aumentando progresivamente hasta situarse en 429 centros Ecoescuelas con 130 de ellos galardonados con Bandera Verde en el curso 2010/11.

La participación en este programa es completamente voluntaria por parte de los centros educativos, pudiéndose acoger cualquier centro escolar que así lo desee. Se oferta para las etapas de Infantil, Primaria y Secundaria.

En la Comunidad Autónoma de Andalucía son la Consejería de Educación y la Consejería de Medio Ambiente quienes ofertan la Red de Ecoescuelas Andaluza, que lleva funcionando desde el curso escolar 1997/98, incorporándose a los planes y programas ofertados por educación, y enmarcándose dentro del Programa de Educación Ambiental ALDEA que la Consejería de Medio Ambiente pone en marcha anualmente con la finalidad de integrar la educación ambiental al sistema educativo.

Este programa, que parte de un enfoque holístico y participativo, hace partícipe a toda la comunidad educativa y a las autoridades locales, lo que favorece la creación de redes locales de participa-

\section{Educational programs to study: 'Eco- School', 'Youth Parliament' and 'Sure you move'}

The educational programs in which research has focused fall in the areas of environmental education, citizenship education, road safety and public participation, which we present below.

\subsection{Eco-School}

In Spain the Eco-Schools program is developed by the Association of Environmental and Consumer Education (ADEAC) by the coordinating Foundation for Environmental Education (FEE), being focused on the acquisition of citizen attitudes and commitment to the environment at levels of environmental management and certification.

It starts in the school year 1998/1999 with 72 participating centers, a number that has grown steadily to stand at 429 centers with 130 of them Eco-Schools Green Flag awarded in 2010/11.

Participation in this program is completely voluntary on the part of schools, being able to host any school wishing to do so. They offer to the steps of Nursery, Primary and Secondary.

In the Autonomous Community of Andalusia are the Ministry of Education and the Ministry of Environment who offer eco-schools Network Andaluza, which has been running since the 1997/98 school year, joining the plans and programs offered by education, and framed within the ALDEA environmental Education Program that the Ministry of Environment launches annually in order to integrate environmental education into the educational system.

This program, part of a holistic and participatory approach, a partaker of the entire educational community and local authorities, which favors the creation of local networks of participation with the aim of improving the environment and the 
ción con el objetivo de mejorar el entorno y la comunidad. Esta participación se lleva a cabo a partir de diversas etapas, como se muestra en la tabla 1.

Tabla 1. Etapas del programa educativo Ecoescuela

\begin{tabular}{|c|c|}
\hline \multicolumn{2}{|c|}{ Organización } \\
\hline $\begin{array}{l}\text { Comité Ambiental: Se } \\
\text { elige de forma autónoma } \\
\text { y democrática, y tiene re- } \\
\text { presentación de toda la } \\
\text { comunidad educativa. }\end{array}$ & $\begin{array}{l}\text { Auditoría Ambiental: } \\
\text { Analiza las necesidades y } \\
\text { prioridades del centro y } \\
\text { el entorno en donde este } \\
\text { se ubica y posteriormente } \\
\text { se tendrán en cuenta en } \\
\text { los planes de acción a } \\
\text { elaborar. }\end{array}$ \\
\hline \multicolumn{2}{|c|}{ Acción } \\
\hline $\begin{array}{l}\text { Plan de Acción: Se esta- } \\
\text { blecen objetivos y fecha } \\
\text { de puesta en marcha de } \\
\text { las iniciativas, teniéndose } \\
\text { que abordar alguno de } \\
\text { los grandes temas que } \\
\text { trabaja el programa (agua, } \\
\text { residuos, energía, y acción } \\
\text { sobre el entorno). }\end{array}$ & $\begin{array}{l}\text { Código de conducta: Se } \\
\text { elaborará un código de } \\
\text { conducta que recogerá } \\
\text { las acciones y/o compor- } \\
\text { tamientos que deben } \\
\text { cumplir todos los miem- } \\
\text { bros de la comunidad } \\
\text { educativa. }\end{array}$ \\
\hline \multicolumn{2}{|c|}{ Valoración } \\
\hline $\begin{array}{l}\text { Control y evaluación: } \\
\text { Desarrollado el plan de } \\
\text { acción, éste es evaluado } \\
\text { por un jurado convocado } \\
\text { por ADEAC (Asociación } \\
\text { de Educación Ambiental } \\
\text { y del Consumidor) y for- } \\
\text { mado por personal com- } \\
\text { petente en materia de } \\
\text { Educación Ambiental. }\end{array}$ & $\begin{array}{l}\text { Bandera Verde: Galar- } \\
\text { dón que se entrega a los } \\
\text { centros escolares que a } \\
\text { final del curso escolar han } \\
\text { cumplido satisfactoria- } \\
\text { mente su Plan Anual de } \\
\text { Acción y así se haya reco- } \\
\text { nocido desde ADEAC. }\end{array}$ \\
\hline \multicolumn{2}{|c|}{ Difusión } \\
\hline \multicolumn{2}{|c|}{$\begin{array}{l}\text { Información y Comunicación: Es muy importante que } \\
\text { haya una buena política de comunicación. Los resulta- } \\
\text { dos obtenidos deben formar parte de la base de datos } \\
\text { de la Red de Ecoescuelas, para ser compartidos con } \\
\text { todos los participantes. }\end{array}$} \\
\hline
\end{tabular}

Fuente: Elaboración propia. community. This participation is carried out from various stages, as shown in Table 1.

Table 1. Stages of Eco-School educational program

\begin{tabular}{|c|c|}
\hline \multicolumn{2}{|c|}{ Organization } \\
\hline $\begin{array}{l}\text { Environmental Commit- } \\
\text { tee: is elected indepen- } \\
\text { dently and democrati- } \\
\text { cally, and has } \\
\text { representation of the en- } \\
\text { tire educational commu- } \\
\text { nity. }\end{array}$ & $\begin{array}{l}\text { Environmental Audit: } \\
\text { Analyze the needs and } \\
\text { priorities of central and } \\
\text { environment where this } \\
\text { is located and subse- } \\
\text { quently taken into ac- } \\
\text { count in developing ac- } \\
\text { tion plans. }\end{array}$ \\
\hline \multicolumn{2}{|c|}{ Action } \\
\hline $\begin{array}{l}\text { Action Plan: objectives } \\
\text { and date of implementa- } \\
\text { tion of the initiatives are } \\
\text { established, having to } \\
\text { deal with any of the ma- } \\
\text { jor issues that the pro- } \\
\text { gram works (water, } \\
\text { waste, energy, and action } \\
\text { on the environment). }\end{array}$ & $\begin{array}{l}\text { Code of Conduct: a } \\
\text { code of conduct to co- } \\
\text { llect the actions and / or } \\
\text { behaviors that apply to } \\
\text { all members of the edu- } \\
\text { cational community is de- } \\
\text { veloped. }\end{array}$ \\
\hline \multicolumn{2}{|c|}{ Assessment } \\
\hline $\begin{array}{l}\text { Monitoring and evalua- } \\
\text { tion: Developed a plan } \\
\text { of action, it is evaluated } \\
\text { by a panel convened by } \\
\text { ADEAC (Association of } \\
\text { Environmental and Con- } \\
\text { sumer Education) and } \\
\text { composed of competent } \\
\text { personnel in Environ- } \\
\text { mental Education. }\end{array}$ & $\begin{array}{l}\text { Green Flag: Award } \\
\text { which is given to schools } \\
\text { that at the end of the } \\
\text { school year have suc- } \\
\text { cessfully fulfilled its An- } \\
\text { nual Action Plan and this } \\
\text { has been recognized } \\
\text { ADEAC. }\end{array}$ \\
\hline \multicolumn{2}{|c|}{ Diffusion } \\
\hline \multicolumn{2}{|c|}{$\begin{array}{l}\text { Information and Communication: It is very important } \\
\text { to have a good communication policy. The results } \\
\text { should be part of the database of the Network of } \\
\text { eco-schools, to be shared with all participants. Source: } \\
\text { Authors. }\end{array}$} \\
\hline
\end{tabular}

Source: Authors.

[ 238 ] OLGA MORENO FERNÁNDEZ 


\subsection{Parlamento Joven}

Este programa surge de la necesidad de dar voz a la juventud a través de un proyecto pedagógico y de participación que los invite a formar parte de las decisiones políticas locales, de forma que se les empiece a dar voz como ciudadanos y ciudadanas de pleno derecho.Este programa, puesto en marcha en el curso escolar 2004/2005 por el Área de Juventud, Innovación y Formación para el Empleo de la Diputación Provincial de Sevilla, está orientado a la participación de los Institutos de Enseñanza Secundaria. Actualmente, cuenta con cuarenta y tres municipios participantes.

El programa se oferta desde Diputación a los Ayuntamientos, y a través de los Agentes de Dinamización Juvenil (ADJ) se presenta a los centros escolares en el mes de septiembre. La propuesta se realiza por aula, en los niveles de 10 y 20 de Enseñanza Secundaria Obligatoria (ESO), siendo de las aulas que finalmente participen de donde saldrán los 20 parlamentarios y parlamentarias que irán en representación de sus compañeros y compañeras a los plenos municipales donde se propondrán las propuestas pertinentes y se decidirán cuáles se llevarán a cabo ese año en la localidad.

Por su parte, los ayuntamientos se comprometen a llevar a cabo al menos una de las propuestas recibidas por el alumnado que se estudiará previamente y que tendrá dos condicionantes: por un lado, que el ayuntamiento tenga viabilidad de ponerla en marcha, y por otro, que el alumnado pueda formar parte de esta puesta en marcha, implicándose así directamente con la mejora de su localidad.

\subsection{Seguro que te mueves}

El programa Seguro profundiza en la línea educativa desarrollada por Parlamento Joven. Se promueve desde el Área de Ciudadanía, Participación y Cultura de la Diputación de Sevilla, comenzando a funcionar en el curso escolar 2008/2009 con grandes resultados. Su finalidad es incorporar la educación vial a los centros educativos, concienciando al alumnado acerca de la importancia que tienen las normas de seguridad vial y lo que supone su implicación en el entorno.

\subsection{Youth Parliament}

This program stems from the need to give voice to the youth through an educational project and participation to invite them to join local political decisions, so that they start giving voice as citizens with full rights. This program, launched in the academic year 2004/2005 by the Department of Youth, Innovation and Training for Employment of the Provincial de Sevilla, is focused on the participation of Secondary Schools. It currently has forty-three participating municipalities.

The program is offered from Council to the municipalities, through the Youth Agents Revitalization (YAR) to schools comes in the month of September. The proposal is made by classroom at levels 1 and 2 of Secondary Education, being finally participating classrooms where will the 20 parliamentarians who will represent their colleagues to full municipal where relevant proposals will be proposed and decide which will be held this year in the town. .

Meanwhile, municipalities undertake to carry out at least one of the proposals received by the students to be studied previously and have two conditions: first, that the city has feasibility to implement it, and secondly, that students can be part of this launch, and engaging directly with improving their locality.

\subsection{Sure you move}

Insurance program delves into the educational line developed by Youth Parliament. It is promoted from the Department of Citizenship, Participation and Culture Council of Seville, starting to work in the school year 2008/2009 with great results. Its purpose is to incorporate road safety education to schools, raising awareness to students about the importance of road safety rules and implying its involvement in the environment.

This topic is selected after detecting that failure codes movement is one of the leading cau- 
Este tema se selecciona tras detectarse que el incumplimiento de los códigos de circulación es una de las primeras causas de mortalidad y lesiones irreversibles entre la población más joven, así lo reseña la Cruz Roja en 2012, señalando que los accidentes de tráfico son la primera causa de muerte en España entre los 15 y los 29 años.

Sin duda, estos datos reflejan la necesidad de incorporar a las aulas un programa educativo que conciencie al alumnado sobre la importancia de la seguridad vial, el respeto de sus normas y las consecuencias que se derivan de su incumplimiento, abordando también, una perspectiva socio-ambiental desde el ámbito de la conducción económica, los transportes públicos y colectivos como alternativa y el conocimiento de la contaminación acústica y sus repercusiones a nivel social y ambiental. Los contenidos que se van a abordar en este programa se han agrupado en 4 bloques, como se muestra en la tabla 2:

Tabla 2. Bloques de contenido del programa educativo Seguro que te mueves

\begin{tabular}{|c|c|}
\hline $\begin{array}{c}\text { Normativa Vial: } \\
\text { legislación y causas de } \\
\text { multas }\end{array}$ & $\begin{array}{c}\text { Conducción: vehículos y } \\
\text { peatones, prevención y } \\
\text { mantenimiento }\end{array}$ \\
\hline $\begin{array}{l}\text { Señales y órdenes de los } \\
\text { agentes de circulación.Se- } \\
\text { máforos, señales vertica- } \\
\text { les, señales de reglamen- } \\
\text { tación, señales de } \\
\text { indicación, marcas viales. }\end{array}$ & $\begin{array}{l}\text { Normas generales de } \\
\text { comportamiento respecto } \\
\text { a los ciclistas y peato- } \\
\text { nes. Normas generales y } \\
\text { prioridad de paso ciclis- } \\
\text { tas.Prioridad de paso de } \\
\text { los conductores sobre } \\
\text { peatones. }\end{array}$ \\
\hline $\begin{array}{l}\text { Consecuencias: } \\
\text { salud y seguridad }\end{array}$ & $\begin{array}{l}\text { El entorno:medioam- } \\
\text { biente y ahorro }\end{array}$ \\
\hline $\begin{array}{l}\text { Normas generales de } \\
\text { comportamiento.Normas } \\
\text { sobre bebidas alcohóli- } \\
\text { cas. Normas sobre estupe- } \\
\text { facientes, psicotrópicos, } \\
\text { estimulantes u otras sus- } \\
\text { tancias análogas. }\end{array}$ & $\begin{array}{l}\text { Conducción } \\
\text { económica.Transportes } \\
\text { alternativos.Transportes } \\
\text { colectivos.Contaminación } \\
\text { acústica. }\end{array}$ \\
\hline
\end{tabular}

Fuente: Elaboración propia a partir de los datos ofrecidos por Oriens (Secretaría Técnica curso 2011/12). ses of mortality and irreversible injuries among the younger population, so review the Red Cross Organization in 2012, noting that traffic accidents are the first cause of death in Spain between 15 and 29 years.

Undoubtedly, these data reflect the need to incorporate into the classroom an educational program that sensitize the students about the importance of road safety, respect their rules and consequences of non-compliance, addressing also a socio- environment perspective from the field of economic management, public transport and collective alternative and knowledge of noise pollution and its impact on social and environmental level.

The content that will be addressed in this program are grouped into 4 blocks, as shown in table 2 .

Table 2. Blocks contents of curriculum the educational program Sure you move

\begin{tabular}{|l|l|}
\hline $\begin{array}{c}\text { Road Rules: } \\
\text { legislation and causes of } \\
\text { fines }\end{array}$ & $\begin{array}{c}\text { Driving: vehicles and } \\
\text { pedestrians, prevention } \\
\text { and maintenance }\end{array}$ \\
\hline $\begin{array}{l}\text { Signs and police com- } \\
\text { mands circulation. } \\
\text { Traffic lights, vertical } \\
\text { signs, regulatory signs, dis- } \\
\text { play signs, road markings } \\
\text { General rules of behavior } \\
\text { from cyclists and pedes- } \\
\text { trians. } \\
\text { General rules and cyclists' } \\
\text { priority step. } \\
\text { Priority Pass drivers } \\
\text { about pedestrians }\end{array}$ \\
\hline $\begin{array}{c}\text { Consequences: } \\
\text { health and safety }\end{array}$ & $\begin{array}{l}\text { The setting: } \\
\text { environment and saving }\end{array}$ \\
\hline $\begin{array}{l}\text { General rules of behavior. } \\
\text { Rules on alcohol. } \\
\text { Rules on narcotics, psy- } \\
\text { chotropic drugs, stimu- } \\
\text { lants or similar substan- } \\
\text { ces. }\end{array}$ & $\begin{array}{l}\text { Economical driving. } \\
\text { Alternative transport. } \\
\text { Public transport. } \\
\text { Noise pollution. }\end{array}$ \\
\hline
\end{tabular}

Source: Development based on data provided by Oriens (Technical Secretariat 2011/12)

[ 240 ] OLGA MORENO FERNÁNDEZ 


\section{Metodología de Investigación}

Como señalamos anteriormente, esta investigación se enmarca dentro de una metodología cualitativa. La recogida de datos se ha llevado a cabo a partir de un cuestionario de preguntas abiertas, entrevistas semi-estructuradas, y grupos de discusión. El haber utilizado diferentes instrumentos metodológicos nos ha permitido triangular los resultados obtenidos, dándoles mayor fiabilidad, pues cuanto mayor es el grado de triangulación, mayor es la fiabilidad de las conclusiones alcanzadas (Denzin, 1970).

El cuestionario se ha realizado a partir de las técnicas propias de la investigación educativa, para lo que ha efectuado un primer borrador que ha sido examinado por expertos; la realización de un ensayo piloto para analizar la validez del cuestionario y la reelaboración del mismo en función de los resultados obtenidos de la prueba piloto.

El cuestionario definitivo (véase anexo) se ha propuesto a 177 alumnos de seis centros diferentes, todos ellos centros públicos de Andalucía. Estos 177 estudiantes participantes en los programas educativos, definidos anteriormente, han constituido la muestra.

La selección de la muestra se ha realizado en base a un conjunto de criterios: aquellos centros escolares a los que hemos podido tener fácil acceso, se han mostrado dispuestos a participar, se facilitaba la presencia del investigador así como facilidad para cerrar un calendario de trabajo. También se ha tenido presente que los centros presentaran diversas características, tales como que se enmarcaran en distintos contextos geográficos, que las localidades variaran en cuánto a tamaño, que los programas se complementaran con otros en alguno de los casos, etc., quedando así conformada por dos centros de cada uno de los programas analizados

En concreto, un $38 \%$ son niños y un $62 \%$ niñas, y oscilan entre los 11 y los 17 años de edad, cursando entre $5^{\circ}$ de Educación Primaria (EP) y $4^{\circ}$ de Educación Secundaria Obligatoria (ESO), tal y como se presenta en el gráfico 1.

\section{Research Methodology}

As noted above, this research is part of a qualitative methodology. Data collection was carried out from an open-ended questionnaire, semi-structured interviews and focus groups. The methodological tools using different triangular allowed us the results obtained, giving improved reliability, since the greater the degree of triangulation, the greater the reliability of the conclusions reached (Denzin, 1970).

The questionnaire was made from their own educational research techniques, for which it has made a first draft that has been examined by experts; conducting a pilot test to analyze the validity of the questionnaire and reprocessing the same depending on the results of the pilot.

The final questionnaire (see Annex) has been proposed to 177 students from six different schools, all public schools in Andalusia. These 177 participants in educational programs students, as defined above, have constituted the sample.

The sample selection was made based on a set of criteria: those schools to which we could have easy access, have been willing to participate, the presence of the researcher as well as ease was provided to close a work Schedule. It has also been mindful that schools present different characteristics, such as to be framed in different geographical contexts, locations vary in size, shape, that programs be supplemented by others in any of the cases, etc., thus being formed two centers of each of the programs analyzed.

Specifically, $38 \%$ are boys and $62 \%$ girls, ranging between 11 and 17 years old, studying between 5th and 4th Primary Education Secondary Education, as presented in Graphic 1. 
Gráfico 1. Distribución de la muestra por sexo

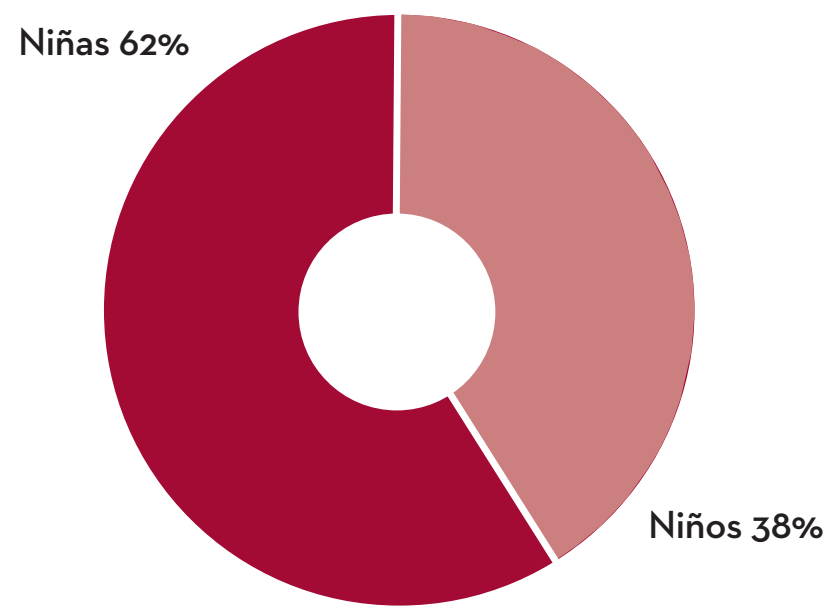

Fuente: Elaboración Propia.

Respecto a la participación en los programas educativos, un 25\% pertenece a Ecoescuela, un 50\% a Parlamentos Joven, y otro 25\% a Seguro que te mueves. En el gráfico 2 se visualiza mejor la distribución de los participantes según el curso escolar. El cuestionario se pasó en sesiones ordinarias de clase.

Gráfico 2. Distribución de la muestra por curso académico

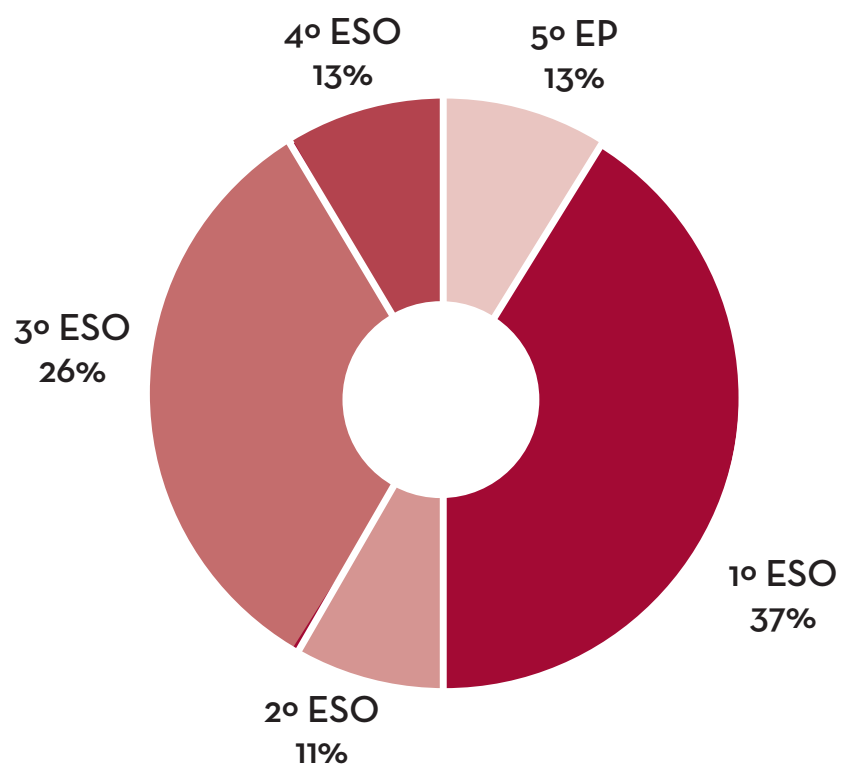

Fuente: Elaboración Propia.

Se han realizado, además, grupos de discusión y entrevistas en cada uno de los centros participantes en el estudio, con la finalidad de aclarar y profundizar en algunos de los resultados obtenidos a partir de los cuestionarios. Para los grupos
Graphic 1. Distribution of the sample for sex.

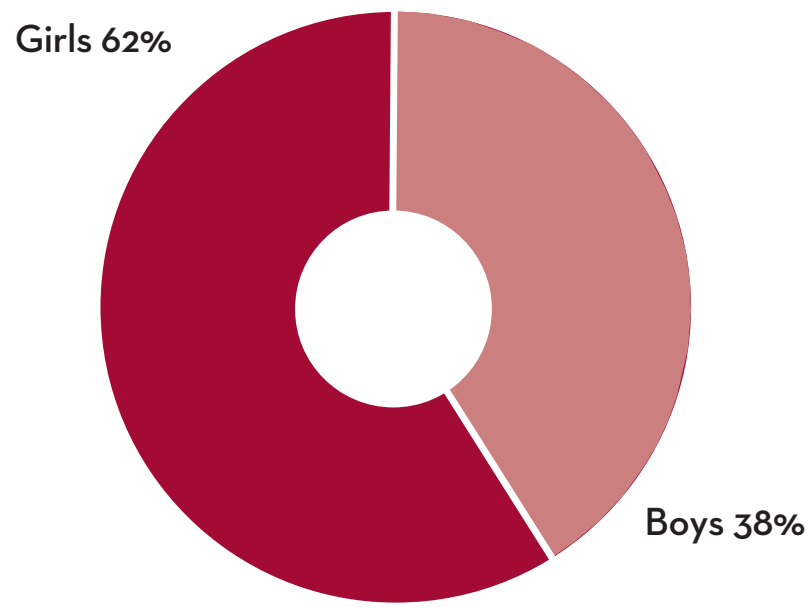

Fuente: Elaboración Propia.

Regarding the participation in educational programs, $25 \%$ belongs to Eco-School, 50\% to Parliament Young, and another 25\% Sure you move. The Graphic 2 shows the distribution of participants is best viewed as the school year. The questionnaire was passed in regular class sessions.

Graphic 2. Distribution of the sample for academic course



Source: Authors.

Also have been conducted focus groups and interviews in each of the centers participating in the study, in order to clarify and deepen some of the results obtained from the questionnaires. To focus groups and interviews were randomly se-

[ 242 ] OLGA MORENO FERNÁNDEZ

SIPS - PEDAGOGIA SOCIAL. REVISTA INTERUNIVERSITARIA [1139-1723 (2015) 26, 229-261] TERCERA ÉPOCA 
de discusión y las entrevistas se eligió al azar alumnado que anteriormente había realizado el cuestionario.

Para la codificación de los datos, se han establecido categorías relacionadas con la educación ambiental, la educación para la ciudadanía, la participación y la ciudadanía planetaria, que a su vez, se han subdividido en tres subcategorías ( $a, b$, y $c$ ), que presentan una escala de progresión de conocimiento (García Díaz, 1998; García Pérez, 2000) lo que se ha denominado cosmovisión analítica (nivel básico de conocimiento), cosmovisión sincrética (nivel más complejo de conocimientos) y aproximación a una cosmovisión sistémica o conocimiento deseable (visión de interacción entre las causas y consecuencias derivadas de la actuación del ser humano en el medio ambiente) (véase tabla 3). A su vez, estas subcategorías se han vuelto a subdividir en valores, que van desde el valor 0 o respuestas no clasificables al valor 3 que representan el conocimiento más deseable en función de la categoría y subcategoría en la que se sitúe la muestra de estudio.

Posteriormente, una vez categorizados los datos se ha procedido a la codificación de los mismos. El análisis de la información se ha realizado a partir de una tabla de Excel para el caso de los cuestionarios y del software de análisis cualitativo Atlas.Ti, en su versión 6.2, para las entrevistas y grupos focales. Para la codificación se han asignado códigos descriptivos, así SQ: Seguro que te mueves, PJ: Parlamento Joven, ECO: Ecoescuela y C: Cuestionario, E: Entrevista y GD: Grupo de discusión. La utilización de varios instrumentos de recogida de datos nos ha permitido triangular los datos, lo que nos ha permitido obtener una visión global de los individuos que integran la muestra y aproximarnos lo mejor posible a las opiniones emitidas por los mismos, para llegar a las conclusiones de investigación. lected students who had previously completed the questionnaire.

For the coding of data, have established categories related to environmental education, education for citizenship, participation and global citizenship, which in turn, have been subdivided into three subcategories ( $a, b, y c)$, having a scale progression of knowledge (García Díaz, 1998; García Pérez, 2000) what is called analytical worldview (basic level of knowledge), syncretic worldview (more complex level of knowledge) and approach to systemic worldview or desirable knowledge (vision of interaction between the causes and consequences of the actions of human beings on the environment) (Table 3). In turn, these subcategories are again subdivided into values ranging from $\mathrm{O}$ or not classifiable responses to the value 3 which represent the most desirable knowledge based on the category and subcategory in which the study sample is placed.

Later, once categorized data have proceeded to codify them. The data analysis was performed from an Excel table for the case of questionnaires and qualitative analysis Atlas.ti software, version 6.2, for interviews and focus groups. For encoding descriptive codes have been assigned and SM: Sure you move, PJ: Youth Parliament, ECO: Eco-School and C: Questionnaire, E: Interview and GD: Focus group. Using multiple data collection tools allowed us to triangulate the data, which has allowed us to obtain an overview of the individuals that make up the sample and best approach to the views expressed by them, to reach conclusions research. 
Tabla 3. Categorías y subcategorías de análisis de la investigación

\begin{tabular}{|c|c|c|c|}
\hline \multicolumn{4}{|c|}{ Subcategorías de Análisis } \\
\hline $\begin{array}{l}\text { Categorías de } \\
\text { análisis }\end{array}$ & $\begin{array}{l}\text { COSMOVISIÓN } \\
\text { SINCRÉTICA }\end{array}$ & $\begin{array}{l}\text { COSMOVISIÓN } \\
\text { ANALÍTICA }\end{array}$ & $\begin{array}{l}\text { APROXIMACIÓN A UNA } \\
\text { COSMOVISIÓN SISTÉMICA }\end{array}$ \\
\hline $\begin{array}{l}\text { Categoría 1: } \\
\text { Presencia y } \\
\text { tratamiento } \\
\text { de problemas } \\
\text { socio-ambien- } \\
\text { tales }\end{array}$ & $\begin{array}{l}\text { Identificación de referencias } \\
\text { ambientales en las dimensio- } \\
\text { nes identificadas } \\
\text { Este valor se caracteriza por } \\
\text { centrarse en un nivel básico de } \\
\text { conocimientos, entendiendo } \\
\text { estos por una formulación ge- } \\
\text { nérica, imprecisa, poco estruc- } \\
\text { turada. Se encuentran referen- } \\
\text { cias a la E. A. pero a niveles } \\
\text { simples, reduciendo su presen- } \\
\text { cia a actividades que tienen } \\
\text { que ver con la naturaleza } \\
\text { (huerto escolar, reciclaje, plan- } \\
\text { tar árboles, reducir la contami- } \\
\text { nación,...). No se estructura } \\
\text { cambio cognitivo de los desti- } \\
\text { natarios a los que se dirigen los } \\
\text { programas, entendiendo a es- } \\
\text { tos como todos aquellos usua- } \\
\text { rios que intervienen en el pro- } \\
\text { ceso de E-A de los mismos } \\
\text { (docentes, discentes y agentes } \\
\text { de dinamización). }\end{array}$ & $\begin{array}{l}\text { Identificación de referencias } \\
\text { ambientales en las dimensio- } \\
\text { nes identificadas con cone- } \\
\text { xión a problemas } \\
\text { Este valor se caracteriza por } \\
\text { centrarse en un nivel más com- } \\
\text { plejo de conocimientos, enten- } \\
\text { diendo estos por una formula- } \\
\text { ción detallada, estructurada, } \\
\text { con cierto grado de explicación } \\
\text { (ya sea a nivel local, bien a es- } \\
\text { cala planetaria, o ambas). Se } \\
\text { encuentran referencias a la E. } \\
\text { A. pero a niveles más comple- } \\
\text { jos, relacionando la presencia } \\
\text { de E. A. no sólo con activida- } \\
\text { des que tienen que ver con la } \\
\text { naturaleza (huerto escolar, reci- } \\
\text { claje, plantación de árboles, re- } \\
\text { ducción de los niveles de con- } \\
\text { taminación,...), sino } \\
\text { relacionando estas con proble- } \\
\text { mas sociales implícitos y favo- } \\
\text { reciendo actitudes procedi- } \\
\text { mentales de implicación en } \\
\text { dichas problemáticas, y detec- } \\
\text { tando niveles básicos de com- } \\
\text { promiso. }\end{array}$ & $\begin{array}{l}\text { Manifestaciones encaminadas } \\
\text { a solucionar problemas socio- } \\
\text { ambientales } \\
\text { Este valor incorpora una visión } \\
\text { de interacción entre las causas } \\
\text { y consecuencias derivadas de } \\
\text { la actuación del ser humano en } \\
\text { el medio ambiente. Se encuen- } \\
\text { tran referencias a la E. A. a ni- } \\
\text { veles complejos, relacionándola } \\
\text { no sólo con actividades que tie- } \\
\text { nen que ver con la naturaleza } \\
\text { (huerto escolar, reciclaje, plan- } \\
\text { tación de árboles, reducción de } \\
\text { los niveles de contaminación,...), } \\
\text { sino también con problemas } \\
\text { sociales implícitos, favore- } \\
\text { ciendo actitudes procedimen- } \\
\text { tales de implicación en dichas } \\
\text { problemáticas, detectando ma- } \\
\text { nifestaciones de compromiso } \\
\text { con los problemas socio-am- } \\
\text { bientales y planteando alterna- } \\
\text { tivas para darles respuesta. Se } \\
\text { estructura cambio cognitivo de } \\
\text { los destinatarios a los que se } \\
\text { dirigen los programas, enten- } \\
\text { diendo a estos como todos } \\
\text { aquellos usuarios que intervie- } \\
\text { nen en el proceso de E-A de } \\
\text { los mismos (docentes, discen- } \\
\text { tes y agentes de dinamización). }\end{array}$ \\
\hline
\end{tabular}

[ 244 ] OLGA MORENO FERNÁNDEZ

SIPS - PEDAGOGIA SOCIAL. REVISTA INTERUNIVERSITARIA [1139-1723 (2015) 26, 229-261] TERCERA ÉPOCA 
Table 3. Categories and sub-analysis of research

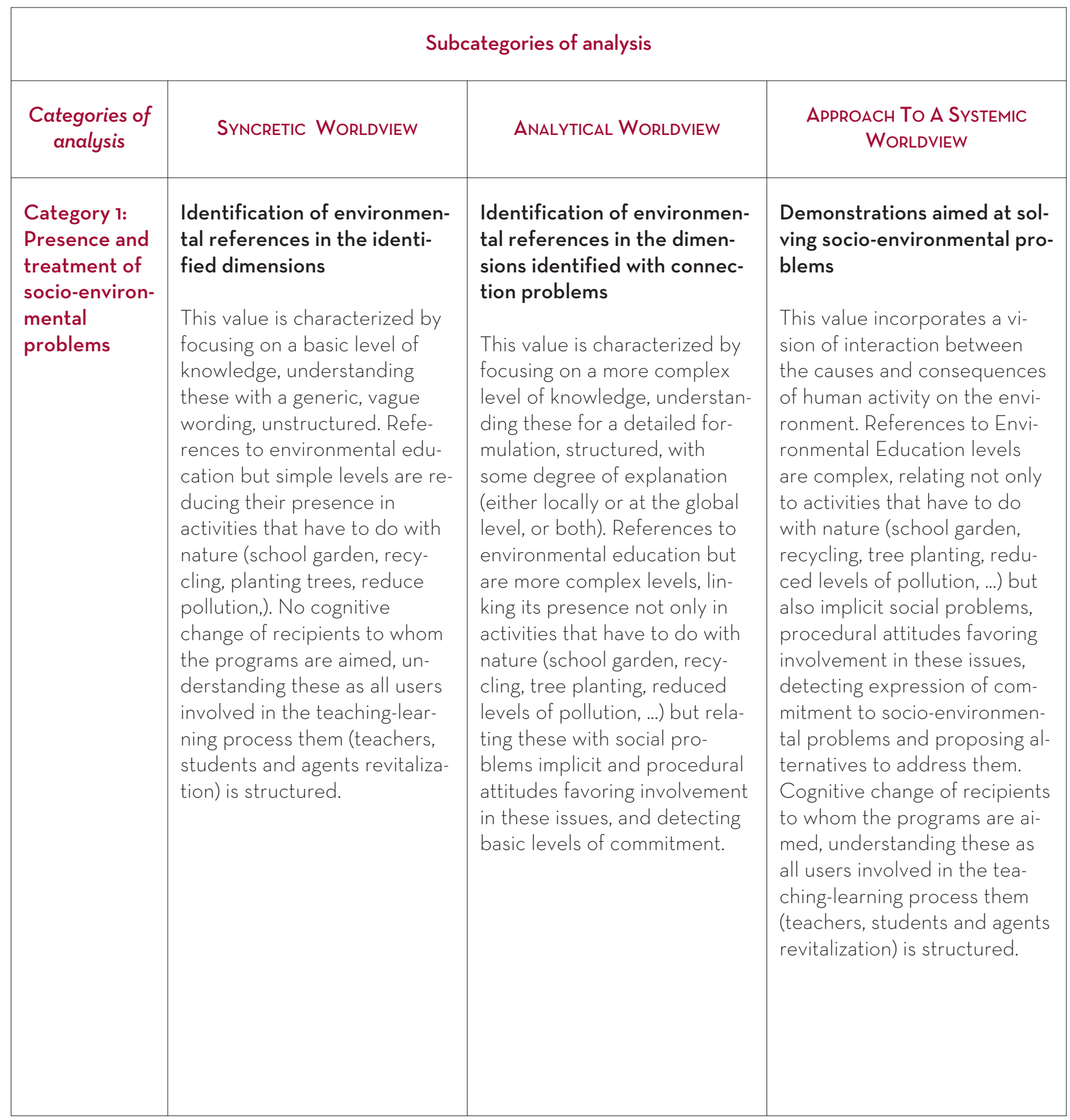




\begin{tabular}{|c|c|c|c|}
\hline \multicolumn{4}{|c|}{ Subcategorías de Análisis } \\
\hline $\begin{array}{l}\text { Categorías de } \\
\text { análisis }\end{array}$ & $\begin{array}{l}\text { COSMOVISIÓN } \\
\text { SINCRÉTICA }\end{array}$ & $\begin{array}{l}\text { COSMOVISIÓN } \\
\text { ANALÍTICA }\end{array}$ & $\begin{array}{l}\text { APROXIMACIÓN A UNA } \\
\text { COSMOVISIÓN SISTÉMICA }\end{array}$ \\
\hline $\begin{array}{l}\text { Categoría 2: } \\
\text { Presencia y } \\
\text { tratamientode } \\
\text { problemas } \\
\text { ciudadanos }\end{array}$ & $\begin{array}{l}\text { Identificación de referencias } \\
\text { cívicas en las dimensiones } \\
\text { identificadas } \\
\text { Este valor se centra en un nivel } \\
\text { básico de conocimientos, en- } \\
\text { tendiendo estos por una for- } \\
\text { mulación genérica, imprecisa, y } \\
\text { poco estructurada. Se encuen- } \\
\text { tran referencias a la E. p. C. } \\
\text { pero a niveles simples, redu- } \\
\text { ciendo su presencia a conteni- } \\
\text { dos de carácter conceptual } \\
\text { que tienen que ver con los te- } \\
\text { mas planteados como de obli- } \\
\text { gado conocimiento dentro de } \\
\text { una ciudadanía democrática } \\
\text { (constitución, integración, con- } \\
\text { ceptos básicos como empatía o } \\
\text { asertividad,... ), pero en las que } \\
\text { no se estructura cambio cogni- } \\
\text { tivo de los destinatarios a los } \\
\text { que se dirigen los programas, } \\
\text { entendiendo a estos como to- } \\
\text { dos aquellos usuarios que in- } \\
\text { tervienen en el proceso de E-A } \\
\text { de los mismos (docentes, dis- } \\
\text { centes y agentes de dinamiza- } \\
\text { ción). }\end{array}$ & $\begin{array}{l}\text { Identificación de referencias } \\
\text { cívicas en las dimensiones } \\
\text { identificadas con conexión a } \\
\text { problemas } \\
\text { Este valor se centra en un nivel } \\
\text { más complejo de conocimien- } \\
\text { tos, entendiendo estos por una } \\
\text { formulación detallada, estructu- } \\
\text { rada, y con cierto grado de ex- } \\
\text { plicación (ya sea a nivel local, } \\
\text { bien a escala planetaria, o am- } \\
\text { bas). Se encuentran referencias } \\
\text { a la E. p. C. donde se relaciona } \\
\text { su presencia no sólo con con- } \\
\text { tenidos de carácter conceptual } \\
\text { que tienen que ver con los te- } \\
\text { mas planteados como de obli- } \\
\text { gado conocimiento dentro de } \\
\text { una ciudadanía democrática } \\
\text { (constitución, integración, con- } \\
\text { ceptos básicos como empatía o } \\
\text { asertividad,... ), sino con proble- } \\
\text { máticas sociales implícitas a es- } \\
\text { cala local, planetaria, o ambas y } \\
\text { favoreciendo actitudes proce- } \\
\text { dimentales de implicación en } \\
\text { dichas problemáticas, aunque } \\
\text { detectando aún niveles básicos } \\
\text { de compromiso. }\end{array}$ & $\begin{array}{l}\text { Manifestaciones encaminadas } \\
\text { a solucionar problemas socia- } \\
\text { les que requieran de una im- } \\
\text { plicación ciudadana } \\
\text { Este valor incorpora una visión } \\
\text { de interacción entre las causas } \\
\text { y consecuencias derivadas de } \\
\text { la actuación del ser humano en } \\
\text { su entorno social. Se encuen- } \\
\text { tran referencias a la E. p. C. a } \\
\text { niveles complejos, relacio- } \\
\text { nando su presencia no sólo con } \\
\text { contenidos de carácter con- } \\
\text { ceptual que tienen que ver con } \\
\text { los temas planteados como de } \\
\text { obligado conocimiento dentro } \\
\text { de una ciudadanía democrática } \\
\text { (constitución, integración, con- } \\
\text { ceptos básicos como empatía o } \\
\text { asertividad,... ), sino relacio- } \\
\text { nando estos con problemas so- } \\
\text { ciales implícitos en su localidad, } \\
\text { comunidad..., planeta y favore- } \\
\text { ciendo actitudes procedimen- } \\
\text { tales de implicación en dichas } \\
\text { problemáticas, detectando } \\
\text { manifestaciones de compro- } \\
\text { miso con los problemas socia- } \\
\text { les y planteando alternativas } \\
\text { para darles respuesta. Se es- } \\
\text { tructura cambio cognitivo de } \\
\text { los destinatarios a los que se } \\
\text { dirigen los programas, enten- } \\
\text { diendo a estos como todos } \\
\text { aquellos usuarios que intervie- } \\
\text { nen en el proceso de E-A de } \\
\text { los mismos (docentes, discen- } \\
\text { tes y monitores). }\end{array}$ \\
\hline
\end{tabular}

[ 246 ] OLGA MORENO FERNÁNDEZ

SIPS - PEDAGOGIA SOCIAL. REVISTA INTERUNIVERSITARIA [1139-1723 (2015) 26, 229-261] TERCERA ÉPOCA 
Subcategories of analysis

\begin{tabular}{|c|c|c|c|}
\hline $\begin{array}{l}\text { Categories of } \\
\text { analysis }\end{array}$ & SYNCRETIC WORLDVIEW & ANALYTICAL WORLDVIEW & $\begin{array}{c}\text { APPROACH TO A SYSTEMIC } \\
\text { WORLDVIEW }\end{array}$ \\
\hline $\begin{array}{l}\text { Category 2: } \\
\text { Presence and } \\
\text { treatment of } \\
\text { citizens } \\
\text { problems }\end{array}$ & $\begin{array}{l}\text { Identification of civic refe- } \\
\text { rences in the identified di- } \\
\text { mensions } \\
\text { This value is centered on a ba- } \\
\text { sic level of knowledge, unders- } \\
\text { tanding these with a generic, } \\
\text { vague wording, and unstructu- } \\
\text { red. References are to Educa- } \\
\text { tion for Citizenship but simple } \\
\text { levels, reducing its presence } \\
\text { conceptual content that deal } \\
\text { with the issues raised and } \\
\text { knowledge required in a de- } \\
\text { mocratic citizenship (creation, } \\
\text { integration, basic concepts } \\
\text { such as empathy and asserti- } \\
\text { veness, ...), but in which no } \\
\text { cognitive change of consig- } \\
\text { nees structure to which pro- } \\
\text { grams are directed, understan- } \\
\text { ding these as all users } \\
\text { involved in the process of tea- } \\
\text { ching and learning of them (te- } \\
\text { achers, students and agents } \\
\text { dynamic). }\end{array}$ & $\begin{array}{l}\text { Identification of civic refe- } \\
\text { rences in the dimensions } \\
\text { identified with connection } \\
\text { problems } \\
\text { This value is focused on a } \\
\text { more complex level of know- } \\
\text { ledge, understanding these for } \\
\text { a detailed formulation, structu- } \\
\text { red, and with some degree of } \\
\text { explanation (either locally or } \\
\text { at the global level, or both). } \\
\text { References to Education for } \\
\text { Citizenship where their pre- } \\
\text { sence is associated not only } \\
\text { with conceptual content that } \\
\text { deal with the issues raised and } \\
\text { knowledge required in a de- } \\
\text { mocratic citizenship (creation, } \\
\text { integration, basic concepts } \\
\text { such as empathy and asserti- } \\
\text { veness are, ...), but with implicit } \\
\text { local, global, or both scale and } \\
\text { procedural attitudes favoring } \\
\text { involvement in these issues, } \\
\text { but detecting even basic le- } \\
\text { vels of commitment to social } \\
\text { issues. }\end{array}$ & $\begin{array}{l}\text { Demonstrations aimed at sol- } \\
\text { ving social problems requi- } \\
\text { ring a citizen involvement } \\
\text { This value incorporates a vi- } \\
\text { sion of interaction between } \\
\text { the causes and consequences } \\
\text { of the actions of human beings } \\
\text { in their social environment. } \\
\text { References are to Education } \\
\text { for Citizenship complex levels, } \\
\text { linking its presence not only } \\
\text { conceptual content that deal } \\
\text { with the issues raised and } \\
\text { knowledge required in a de- } \\
\text { mocratic citizenship (creation, } \\
\text { integration, basic concepts } \\
\text { such as empathy or assertive- } \\
\text { ness, ...) but with implicit lin- } \\
\text { king these social problems in } \\
\text { your local community, ...., pla- } \\
\text { net and procedural attitudes } \\
\text { favoring involvement in these } \\
\text { issues, detecting expressions } \\
\text { of commitment to social pro- } \\
\text { blems and proposing alternati- } \\
\text { ves to address them. Cogni- } \\
\text { tive change of recipients to } \\
\text { whom the programs are ai- } \\
\text { med, understanding these as } \\
\text { all users involved in the tea- } \\
\text { ching-learning process them } \\
\text { (teachers, students and moni- } \\
\text { tors) structure. }\end{array}$ \\
\hline
\end{tabular}




\begin{tabular}{|c|c|c|c|}
\hline \multicolumn{4}{|c|}{ Subcategorías de Análisis } \\
\hline $\begin{array}{l}\text { Categorías de } \\
\text { análisis }\end{array}$ & $\begin{array}{l}\text { COSMOVISIÓN } \\
\text { SINCRÉTICA }\end{array}$ & $\begin{array}{l}\text { COSMOVISIÓN } \\
\text { ANALÍTICA }\end{array}$ & $\begin{array}{l}\text { APROXIMACIÓN A UNA } \\
\text { COSMOVISIÓN SISTÉMICA }\end{array}$ \\
\hline $\begin{array}{l}\text { Categoría 3: } \\
\text { Participación }\end{array}$ & $\begin{array}{l}\text { Referencias a los mecanismos } \\
\text { de participación ciudadana } \\
\text { Este valor se caracteriza por } \\
\text { centrarse en un nivel básico de } \\
\text { conocimientos de la participa- } \\
\text { ción ciudadana, entendiendo } \\
\text { esta por una formulación gené- } \\
\text { rica, imprecisa, y poco estructu- } \\
\text { rada. Se entiende la importa- } \\
\text { ción de la participación, pero } \\
\text { esta se reduce a acciones pun- } \\
\text { tuales dentro de los programas } \\
\text { analizados. }\end{array}$ & $\begin{array}{l}\text { Convicción por conseguir una } \\
\text { ciudadanía crítica } \\
\text { Este valor se caracteriza por } \\
\text { centrarse en un nivel más com- } \\
\text { plejo de conocimientos, enten- } \\
\text { diendo estos por una formula- } \\
\text { ción detallada, estructurada, } \\
\text { con cierto grado de explicación } \\
\text { (ya sea a nivel local, bien a es- } \\
\text { cala planetaria, o ambas) de la } \\
\text { participación. Se entiende la } \\
\text { importación de la participación, } \\
\text { y se entiende no sólo la necesi- } \\
\text { dad de participar en acciones } \\
\text { puntuales dentro de los progra- } \\
\text { mas analizados, sino también la } \\
\text { de participar en el entorno a } \\
\text { través de pequeños gestos. }\end{array}$ & $\begin{array}{l}\text { Compromiso con la solución } \\
\text { de problemas sociales y/o am- } \\
\text { bientales } \\
\text { Este valor incorpora una visión } \\
\text { de interacción entre las causas } \\
\text { y consecuencias derivadas de la } \\
\text { actuación del ser humano en su } \\
\text { entorno social. Se encuentran } \\
\text { referencias a la participación a } \\
\text { niveles complejos, entiende la } \\
\text { importación de la participación, } \\
\text { entendiendo la importancia de } \\
\text { los mecanismos de participa- } \\
\text { ción como generadores de } \\
\text { compromiso para aportar solu- } \\
\text { ciones a los problemas que se } \\
\text { presentan. Participación como } \\
\text { generador de cambios. }\end{array}$ \\
\hline $\begin{array}{l}\text { Categoría 4: } \\
\text { Dimensión } \\
\text { planetaria(co } \\
\text { mpromiso/ide } \\
\text { a de solidari- } \\
\text { dad/responsa- } \\
\text { bilidad) }\end{array}$ & $\begin{array}{l}\text { Referencias a la Educación } \\
\text { Ciudadana Planetaria } \\
\text { Este valor se caracteriza por } \\
\text { centrarse en un nivel básico de } \\
\text { conocimientos, entendiendo } \\
\text { estos por una formulación ge- } \\
\text { nérica, imprecisa, poco estruc- } \\
\text { turada. Se encuentran referen- } \\
\text { cias a la E. C. P. pero a niveles } \\
\text { simples, que se reducen a es- } \\
\text { quemas conceptuales en los } \\
\text { que no se estructura cambio } \\
\text { cognitivo de los destinatarios a } \\
\text { los que se dirigen los progra- } \\
\text { mas, entendiendo a estos como } \\
\text { todos aquellos usuarios que in- } \\
\text { tervienen en el proceso de E-A } \\
\text { de los mismos (docentes, dis- } \\
\text { centes y monitores). }\end{array}$ & $\begin{array}{l}\text { Valoración de la situación so- } \\
\text { cio-ambiental } \\
\text { Este valor se caracteriza por } \\
\text { centrarse en un nivel más com- } \\
\text { plejo de conocimientos, enten- } \\
\text { diendo estos por una formula- } \\
\text { ción detallada, estructurada, } \\
\text { con cierto grado de explicación } \\
\text { (ya sea a nivel local, bien a es- } \\
\text { cala planetaria, o ambas). Se } \\
\text { encuentran referencias a la E. } \\
\text { C. P. pero a niveles más com- } \\
\text { plejos, relacionando problemá- } \\
\text { ticas socio-ambientales locales } \\
\text { con problemáticas socio-am- } \\
\text { bientales que se dan a escala } \\
\text { planetaria y favoreciendo acti- } \\
\text { tudes procedimentales de im- } \\
\text { plicación en dichas problemáti- } \\
\text { cas, pero detectando aún } \\
\text { niveles básicos de compromiso. }\end{array}$ & $\begin{array}{l}\text { Compromiso de conciencia- } \\
\text { ción eco ciudadana planetaria } \\
\text { Este valor incorpora una visión } \\
\text { de interacción entre las causas } \\
\text { y consecuencias derivadas de la } \\
\text { actuación del ser humano en las } \\
\text { problemáticas socio-ambienta- } \\
\text { les que se dan en el mundo. Se } \\
\text { encuentran referencias a la E. } \\
\text { C. P. a niveles complejos, rela- } \\
\text { cionando problemáticas socio- } \\
\text { ambientales locales con proble- } \\
\text { máticas socio-ambientales que } \\
\text { se dan a escala planetaria, favo- } \\
\text { reciendo actitudes procedimen- } \\
\text { tales de implicación en dichas } \\
\text { problemáticas, detectando ma- } \\
\text { nifestaciones de compromiso } \\
\text { con los problemas socio-am- } \\
\text { bientales y planteando alternati- } \\
\text { vas para darles respuesta. Se } \\
\text { estructura cambio cognitivo de } \\
\text { los destinatarios a los que se di- } \\
\text { rigen los programas, enten- } \\
\text { diendo a estos como todos } \\
\text { aquellos usuarios que intervie- } \\
\text { nen en el proceso de E-A de los } \\
\text { mismos (docentes, discentes y } \\
\text { monitores). }\end{array}$ \\
\hline
\end{tabular}

[ 248 ] OLGA MORENO FERNÁNDEZ

SIPS - PEDAGOGIA SOCIAL. REVISTA INTERUNIVERSITARIA [1139-1723 (2015) 26, 229-261] TERCERA ÉPOCA 
Subcategories of analysis

\begin{tabular}{|c|c|c|c|}
\hline $\begin{array}{l}\text { Categories of } \\
\text { analysis }\end{array}$ & SYNCRETIC WORLDVIEW & ANALYTICAL WORLDVIEW & $\begin{array}{c}\text { APPROACH TO A SYSTEMIC } \\
\text { WORLDVIEW }\end{array}$ \\
\hline $\begin{array}{l}\text { Category 3: } \\
\text { Participation }\end{array}$ & $\begin{array}{l}\text { References mechanisms for } \\
\text { citizen participation } \\
\text { This value is characterized by } \\
\text { focusing on a basic level of } \\
\text { knowledge of citizen participa- } \\
\text { tion, understood by a generic, } \\
\text { vague wording, and unstructu- } \\
\text { red. It is understood the im- } \\
\text { port of participation, but this is } \\
\text { reduced to specific actions } \\
\text { within the programs analyzed. }\end{array}$ & $\begin{array}{l}\text { Conviction to achieve critical } \\
\text { citizenship } \\
\text { This value is characterized by } \\
\text { focusing on a more complex } \\
\text { level of knowledge, understan- } \\
\text { ding these for a detailed for- } \\
\text { mulation, structured, with } \\
\text { some degree of explanation } \\
\text { (either locally or at the global } \\
\text { level, or both) of participation. } \\
\text { It is understood the import of } \\
\text { participation, and understood } \\
\text { not only the need to partici- } \\
\text { pate in specific actions within } \\
\text { the programs analyzed, but } \\
\text { also to participate in the envi- } \\
\text { ronment through small gestu- } \\
\text { res. }\end{array}$ & $\begin{array}{l}\text { Commitment to solving social } \\
\text { problems and / or environ- } \\
\text { mental } \\
\text { This value incorporates a vi- } \\
\text { sion of interaction between } \\
\text { the causes and consequences } \\
\text { of the actions of human beings } \\
\text { in their social environment. } \\
\text { References to participation le- } \\
\text { vels are complex, understand } \\
\text { the import of participation, un- } \\
\text { derstanding the importance of } \\
\text { participation mechanisms as } \\
\text { generators commitment to } \\
\text { provide solutions to problems } \\
\text { that arise. Participation in ge- } \\
\text { nerating changes. }\end{array}$ \\
\hline $\begin{array}{l}\text { Category 4: } \\
\text { Planetary di- } \\
\text { mension(com- } \\
\text { mitment / } \\
\text { idea of solida- } \\
\text { rity / respon- } \\
\text { sibility) }\end{array}$ & $\begin{array}{l}\text { References to the Planetary } \\
\text { Citizenship Education } \\
\text { This value is characterized by } \\
\text { focusing on a basic level of } \\
\text { knowledge, understanding } \\
\text { these with a generic, vague } \\
\text { wording, unstructured. Refe- } \\
\text { rences to Citizenship Educa- } \\
\text { tion Planetary but simple le- } \\
\text { vels, which are reduced to } \\
\text { conceptual schemes in which } \\
\text { no cognitive change of consig- } \\
\text { nees structure to which pro- } \\
\text { grams are directed, understan- } \\
\text { ding these as all users } \\
\text { involved in the process are Te- } \\
\text { aching-Learning of them (tea- } \\
\text { chers, students and instruc- } \\
\text { tors). }\end{array}$ & $\begin{array}{l}\text { Assessment of the socio-en- } \\
\text { vironmental situation } \\
\text { This value is characterized by } \\
\text { focusing on a more complex } \\
\text { level of knowledge, understan- } \\
\text { ding these for a detailed for- } \\
\text { mulation, structured, with } \\
\text { some degree of explanation } \\
\text { (either locally or at the global } \\
\text { level, or both). References are } \\
\text { to Citizenship Education Pla- } \\
\text { netary but more complex le- } \\
\text { vels, linking local socio-envi- } \\
\text { ronmental issues with } \\
\text { socio-environmental problems } \\
\text { that occur on a global scale } \\
\text { and procedural attitudes favo- } \\
\text { ring involvement in these is- } \\
\text { sues, but detecting even basic } \\
\text { levels of commitment. }\end{array}$ & $\begin{array}{l}\text { Commitment planetary citi- } \\
\text { zen eco awareness } \\
\text { This value incorporates a vi- } \\
\text { sion of interaction between } \\
\text { the causes and consequences } \\
\text { of the actions of human beings } \\
\text { in the socio-environmental } \\
\text { problems that exist in the } \\
\text { world. References to Plane- } \\
\text { tary Citizenship Education le- } \\
\text { vels are complex, linking local } \\
\text { socio-environmental issues } \\
\text { with socio-environmental pro- } \\
\text { blems that occur on a global } \\
\text { scale, favoring procedural atti- } \\
\text { tudes of involvement in these } \\
\text { issues, detecting expression of } \\
\text { commitment to socio-environ- } \\
\text { mental problems and propo- } \\
\text { sing alternatives to address } \\
\text { them. Cognitive change of re- } \\
\text { cipients to whom the pro- } \\
\text { grams are aimed, understan- } \\
\text { ding these as all users } \\
\text { involved in the teaching-lear- } \\
\text { ning process them (teachers, } \\
\text { students and monitors) struc- } \\
\text { ture. }\end{array}$ \\
\hline
\end{tabular}




\section{Reflexiones del alumnado acerca de la educación ambiental y la educación para la ciudadanía desde una perspectiva planetaria}

La categoría denominada Participación ha sido la que más respuesta ha categorizado, así como la que mayor nivel de conocimiento ha suscitado en el alumnado. Como podemos ver en el gráfico 3, todas las subcategorías han recogido datos en sus distintos niveles, sin embargo, en las tres subcategorías a estudio resaltan las gráficas relativas al valor 20 cosmovisión analítica.

Gráfico 3. Datos comparados a partir de los cuestionarios del alumnado, Categoría 3

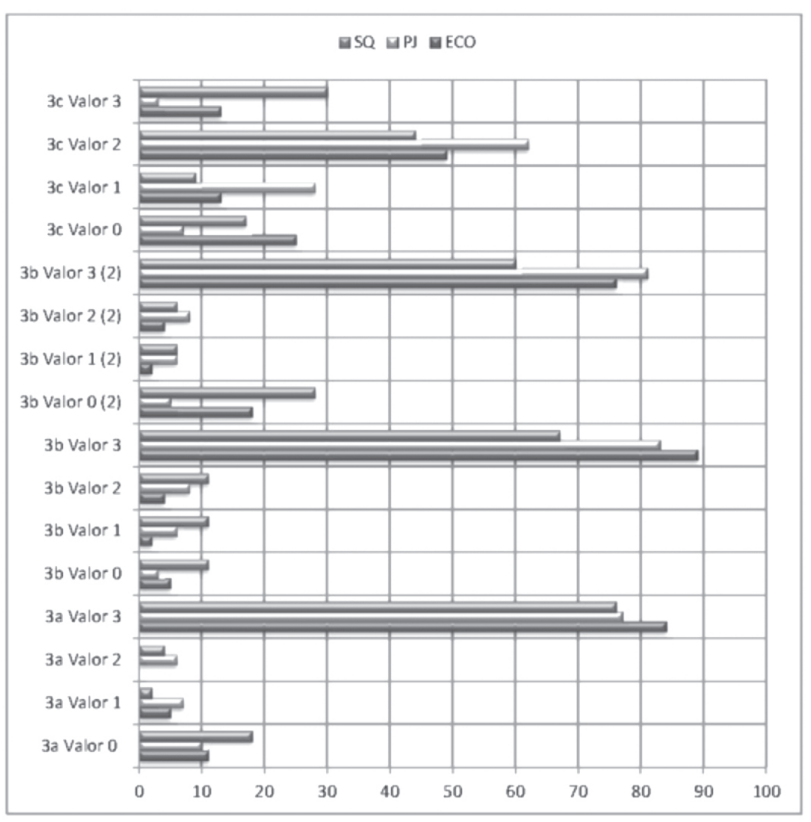

Fuente: Elaboración Propia.

De los datos recogido se extrae que el alumnado entiende los mecanismos de participación y hace referencia a ellos, manifestando que los respectivos programas le han aportado conocimientos útiles que les hace ser mejores ciudadanos y más activos, comprometiéndose con los problemas locales que ven en su comunidad. Entienden que los problemas locales también pueden ser globales y afectar por igual en ambos planos.

De las entrevistas y grupos de discusión se extrae como la mayoría del alumnado está interesado en participar y además le parece importante su participación porque deriva en una mejora del entorno. El alumnado entiende la importación de la participación, y se entiende no sólo la necesidad de parti-

\section{Reflections of students about environ- mental education and citizenship education from a global perspective}

The category called Participation has been the most response has categorized and the higher level of knowledge that has arisen in the student body. As we can see in Graphic 3, all subcategories have collected data at different levels, however, in the three subcategories study highlight the graphic on the value of 2 or analytical worldview.

Graphic 3. Comparative data from student questionnaires, Category 3

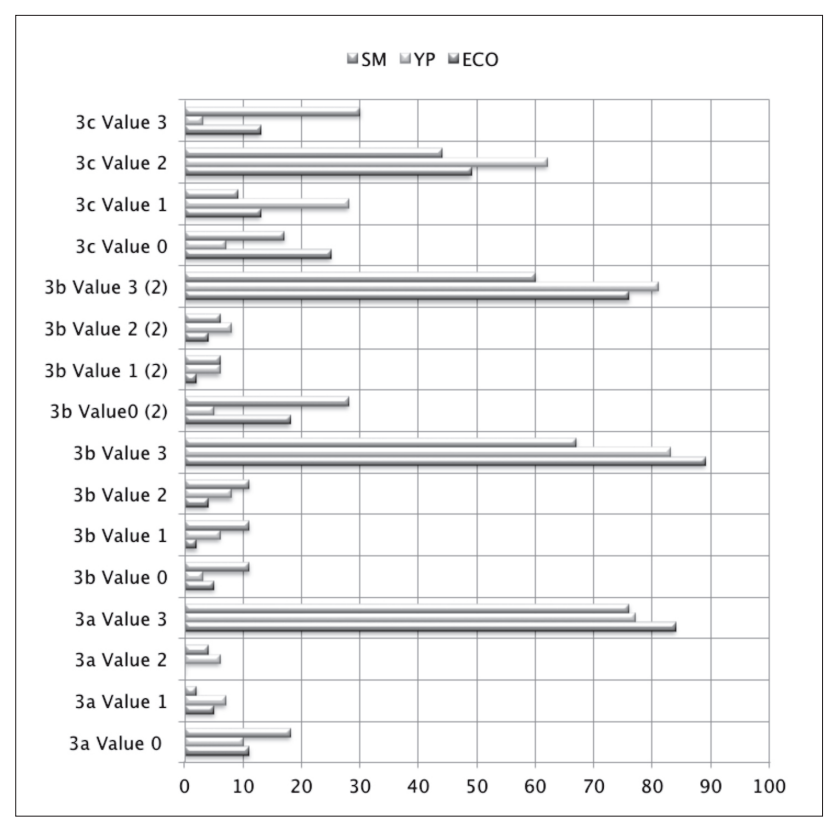

Source: Authors.

Of the collected data is extracted that the students understands the mechanisms of participation and refers to them, stating that the respective programs have provided you with useful knowledge that makes them better citizens and more active, engaging with local problems they see in their community. Entienden que los problemas locales también pueden ser globales y afectar por igual en ambos planos.

Interviews and focus groups are extracted as the majority of students are interested in participating and also seems important because it derives its participation in an improvement of the environment. The students understand the import of participation, and understood not only the need

[ 250 ] OLGA MORENO FERNÁNDEZ 
cipar en acciones puntuales dentro del programa, sino también la de participar en el entorno a través de pequeños gestos. El alumnado expresa su compromiso con su entorno a través de su participación en el programa y lo que está aprendiendo en este, valora el programa positivamente porque entiende que está adquiriendo nuevos conocimientos que les hace reflexionar y ser mejores ciudadanos.

En este caso y para esta categoría, la muestra relativa al alumnado, parece caracterizarse por una cosmovisión analítica, es decir, en un nivel complejo de conocimientos, con capacidad para formular de forma detallada, estructurada y con cierto grado de explicación referencias que tienen que ver con la presencia y el tratamiento de la educación para la ciudadanía relacionándola con problemas sociales implícitos y favoreciendo actitudes procedimentales de implicación en dichas problemáticas.

De los datos obtenidos se desprende que el alumnado entiende los mecanismos de participación social y hace referencia a los mismos, manifestando que los respectivos programas han aportado conocimientos útiles que les hacen ser mejores ciudadanos, más activos y comprometidos con los problemas locales de sus respectivas comunidades, siendo capaz de valorar la situación socio-ambiental local, relacionándola con problemáticas de ámbito global. Alguna de estas cuestiones se pueden leer de los datos obtenidos a partir de los grupos de discusión y cuestionarios realizados en los programas educativos Seguro que te mueves y Parlamento joven.

SQ-GD-A1-[1:11] [2:53-2:131]: ...los problemas medioambientales son por acción de los seres humanos la mayoría (...) a partir de lo que hacen los humanos se crean las catástrofes medioambientales y también las sociales.

SQ-GD-A2-[2:24] [6:1317-6:1592]: ...solemos echarle la culpa a...esto que lo haga el rico, que lo haga el que tiene dinero pero sino ponemos todos de nuestra parte..., cada uno tiene que poner en la medida de sus posibilidades, pero todos algo. No dejarlo todo que lo haga el que puede, todos podemos un poco.

PJ-C-A2: El año pasado no participé en ningún programa, en mi colegio no había programas como éste. Pero este año si he participado y creo que este programa (Parlamento Joven) ayudará a la mejora to participate in specific actions within the program, but also to participate in the environment through small gestures. The students expressed their commitment to their environment through their participation in the program and what you are learning in this, assesses the program positively because it understands that it is acquiring new knowledge that makes them reflect and become better citizens.

In this case and for this category, the sample relating to students, seems characterized by an analytical worldview, i.e., in a complex level of knowledge, ability to formulate in detail, structured and with some degree of explanation references must with the presence and treatment of citizenship education relating it to social problems and implicit attitudes favoring procedural involvement in these issues.

The data obtained suggest that students understand the mechanisms of social participation and refer to them, stating that the respective programs have provided useful insights that make them better citizens, more active and engaged with local problems of their communities being able to assess the local socio-environmental situation, relating to issues of global scope. Some of these issues can be read from the data obtained from focus groups and questionnaires conducted in educational programs Sure you move and Young Parliament.

SM-FG-S1-[1:11] [2:53-2:131]: ... Environmental problems are by action of human beings most (...) from what humans do is create environmental disasters and social too.

SM-FG-S2-[2:24] [6:1317-6:1592]: ... Tend to blame... it do so rich, let him who has money but it put all of us... everyone has to put in the extent possible, but all something. Do not leave everything to do it where you can, can all slightly.

YP-Q-S2: Last year I did not participate in any program in my school there were programs like this. But this year if I participated and I think this program (Youth Parliament) will help improve the

EDUCACIÓN Y CIUDADANÍA PLANETARIA. CONCEPCIONES DEL ALUMNADO PARTICIPANTE EN PROGRAMAS EDUCATIVOS ANDALUCES [ 251 ] 
del pueblo. (...) He aprendido a participar en grupo, a debatir, a reciclar,...

Hacen mención a cuestiones como las consecuencias derivadas de las alteraciones climáticas (terremotos, tsunamis, etc.) y a la pobreza como problemas relevantes que afectan al planeta. Entienden que los problemas locales también pueden ser globales y afectar por igual a ambos planos, aunque reconocen que el relacionar los problemas locales con los problemas globales no les resulta fácil, y no siempre se encuentran capacitados para ello. Es interesante destacar cómo cuando se le pregunta cuál es la actitud que adoptan ante una catástrofe hacen referencia a que ésta es de impacto, es decir, les afecta momentáneamente pero después se les olvida, o de indiferencia, aunque reconocen que no son las adecuadas $y$, para que se realicen cambios la actitud que se debería de llevar a cabo es la de solidaridad, aunque señalan no saber cuáles son los mecanismos que deben poner en marcha para actuar solidariamente, tal y como se desprende de algunas unidades de información codificadas:

SQ-GD-A1-[1:19] [2:1018-2:1233]: ...un terremoto no lo puedes controlar pero la destrucción de la capa de ozono sí, porque si contaminas porque por ejemplo los aerosoles que contaminan muchísimo y si no hace nada con no contaminar pues contribuimos.

SQ-GD-A1-[1:70] [9:290-9:860]: Yo me quedo con la conclusión de que si todos ponemos de nuestra parte podemos hacer algo, no podemos acabar con el problema pero algo podemos hacer. Disminuirlo pero también si ves que estás haciendo algo por solucionarlo y ves a gente que lo empeora es que se te quitan las ganas. Pero además que eso se puede parar...Yo creo que si todos ponemos de nuestra parte podemos hacer que se nos ocurra ahora mismo podemos posponer el problema y que yo me considero impacto (Comentario: hace referencia a que le impactan aquellas noticias que ve en los medios de comunicación pero que después se le olvidan porque no sabe cómo participar o ayudar para aliviar la situación que ha percibido) pero que a partir de ahora voy a intentar ser solidaria y así intentar que no pasen más cosa

ECO-E-A3-[3:20] [4:342-4:458]: A lo mejor si me resulta un poquito difícil ¿no? Pero como estoy apuntada a esto de la ecoescuela, pues me ayuda. town. (...) I learned to participate in a group, to discuss, to recycle, ...

Make mention of issues such as the consequences of climatic changes (earthquakes, tsunamis, etc.) and poverty as relevant issues affecting the planet. Understand that local problems can also be global and affect equally to both planes, while recognizing that local problems related to global problems are not easy, and are not always able to do so. It is interesting to note how when asked what their attitude to disasters refer to it is impact, i.e., momentarily affect them but then they forget, or indifference, but recognize that they are not adequate and so that changes are made to the attitude you should perform is that of solidarity, but say not knowing what mechanisms should be put in place to act in solidarity, as is clear from some units are coded information:

SM-FG-S1-[1:19] [2:1018-2:1233]: ... An earthquake can not control but the destruction of the ozone layer itself, because if you pollute because eg sprays that pollute a lot and if you do nothing to avoid contamination as contribute.

SM-FG-S1-[1:70] [9:290-9:860]: I'm left with the conclusion that if we all do our part we can do something, we can not end the problem but something we can do. Decrease but also if you see you're doing something to solve it and see people that makes it worse is that they take away the desire. But besides that you can stop... I think if we all do our part we can do we can think of right now we can postpone the problem and I consider myself impact (Comment: refers to this news will impact you see in the media but which were later forgotten because he does not know how to participate or help to alleviate the situation perceived) but from now on I will try to be supportive and so try not to spend more thing.

ECO-I-S3-[3:20] [4:342-4:458]: Maybe if I find it a little difficult, no? But as I pointed to this in the Eco-school, since it help me. 
Esta limitación les lleva a manifestar que participan a través de acciones simples y puntuales que también pueden dar respuesta a problemas "glocales", para ello utilizan los mismos mecanismos que utilizarían a nivel local (control del consumo de agua a través de acciones como cerrar el grifo o ducharse en vez de bañarse, reutilizar, reciclar, utilizar transportes alternativos como la bicicleta o los transportes públicos, etc....). De lo que se desprende cuestiones como:

ECO-E-A1- [1:3] [2:56-2:161]: Intentando aportar lo que yo pueda dar y haciendo las cosas bien ¿no? No hacerlas por hacerlas y ya está.

ECO-C-A16: Cuando me estoy duchando que me voy a enjabonar dejo el grifo del agua abierto y en vez de ducharme me baño.

SQ-C-A2O: Me ducho, cierro el grifo mientras me lavo los dientes, cierro bien el grifo y evito que no gotee.

PJ-C-A85: No tiro basura al suelo, cierro el grifo de la ducha mientras me enjabono y me cepillo los dientes.

Cuando se les plantea si se siente parte de una comunidad local o global, el 87,6\% afirma sentirse parte de una comunidad mundial, es decir, "ciudadanos del mundo", justificándolo en que se siente ciudadano del planeta en cuánto que viven en éste. Sólo el 12,4\% ha manifestado sentirse parte de su localidad, que ha coincidido con el alumnado perteneciente a la etapa de primaria. Sin embargo, manifiestan no conocer en que se basa la ciudadanía planetaria, ya que no están familiarizados con el término como tal.

Los niños y jóvenes pasan un número de horas considerables al día frente a la televisión, en el caso español, durante el primer semestre de 2012 los menores de entre 4 y 12 años vieron la televisión una media 2 horas y 44 minutos al día, además de estar expuestos a información que reciben a través de diversos dispositivos tecnológicos como teléfonos móviles o tabletas y desde las redes sociales como Tuenti, Facebook o Twitter.

Esta exposición influye en un mayor conocimiento de lo que está ocurriendo en el mundo, la globalización de las comunicaciones también ha in-
This limitation leads them to manifest involved through simple and precise actions that can also respond to glocals problems, for it uses the same mechanisms that would use locally (control water consumption through actions such as closing the faucet or shower instead of a bath, reuse, recycle, use alternative transportation such as bicycles and public transport, etc.). Examples are:

ECO-I-S1- [1:3] [2:56-2:161]: Trying to contribute what I can give and doing well, no? No make for them and that's it.

ECO-Q-S16: When I'm taking a shower soaping I'II leave the tap open water and showering instead of bathing me.

SM-Q-S2O: I shower, I close the tap while brushing my teeth, I close the tap well and avoid not dripping.

YP-Q-S85: Do not throw trash on the ground, I close the faucet in the shower while I soap and brush my teeth.

When confronted if you feel part of a local or global community, $87.6 \%$ claim to feel part of a global community, i.e. planetary citizenships, justifying it feels citizen of the planet on how to live in this one. Only $12.4 \%$ said being part of the town, which has coincided with the students belonging to the stage of Primary Education. However, manifests not know where global citizenship is based, as they are not familiar with the term as such.

Children and young people spend considerable number of hours per day watching television in the Spanish case, during the first half of 2012 children aged between 4 and 12 years watched television an average 2 hours and 44 minutes a day, plus to be exposed to information they receive through various technological devices such as mobile phones or tablets and from social networks such as MySpace, Facebook or Twitter.

This exposure affects a better understanding of what is happening in the world, globalization of communications has also influenced the knowledge we have about what happens beyond the 
fluido en el conocimiento que se tiene acerca de lo que ocurre más allá de la propia localidad. El alumnado entrevistado de la provincia de Sevilla relata catástrofes que han ocurrido en diferentes partes del mundo, en concreto, hacen referencia a lo ocurrido en Murcia con el terremoto de Lorca o en Haití, lo que demuestra que tienen una percepción global que repercute en un mayor conocimiento del mundo.

Que el alumnado se sienta parte de una ciudadanía planetaria, aunque no entienda el concepto a grandes rasgos, $y$ considere que se debe de actuar desde la solidaridad, es un paso importante para poder comenzar a trabajar desde la escuela.

\section{Conclusiones}

De los resultados obtenidos, podemos afirmar que, aunque estos programas educativos, actualmente, no están contribuyendo, de forma explícita a la adquisición y desarrollo de valores ciudadanos planetarios, están sentando las bases y avanzando para que esto se convierta en una realidad.

Consideramos que el hecho de que el alumnado haya llegado a tener estas concepciones acerca de la ciudadanía planetaria, cuando reconoce no haber escuchado hablar antes de la misma, está muy relacionado por el impacto mediático que ejercen los medios de información y comunicación a los que están expuestos.

Esto se brinda como una gran oportunidad si se establece como punto de partida que el profesorado puede aprovechar a la hora de trabajar desde una perspectiva de educación ciudadana planetaria en las aulas.

Las actitudes y valores adquiridos a través de la participación en los distintos programas van en esta línea, aunque aún es necesario darles un enfoque más ambicioso, donde lo local y lo global adopten una perspectiva "glocal", ya que aunque se ha percibido que el alumnado conoce a nivel básico los problemas socio-ambientales que suceden en el planeta, y en consecuencia, que sus dimensiones locales están relacionadas con otras dimensiones globales, se detecta que la relación local-global es una tarea pendiente en la que seguir trabajando. $Y$ es que, como afirmaba $\mathrm{De} \mathrm{Paz}$ (2004), ambos términos son parte de una misma realidad y por lo tanto es town itself. The students interviewed in the province of Seville tells disasters that have occurred in different parts of the world, specifically referring to what happened in Murcia with the earthquake of Lorca or in Haiti, demonstrating that they have a perception global that impact in a greater knowledge of the world.

That students of a planetary citizenship feel, but do not understand the concept broadly and consider to be acting out of solidarity, it is important to start working from school step.

\section{Conclusions}

From the results, we can say that although these educational programs currently are not contributing explicitly to the acquisition and development of planetary citizenship values are laying the foundation and progress for this to become a reality.

We believe that students have come to have these ideas about global citizenship, it recognizes not have heard before it, is closely related by the media impact exerted by the media and communication which are exposed.

This provides a great opportunity if it is set as a starting point that teachers can take when working from a perspective of global citizenship education in the classroom.

The attitudes and values acquired through participation in various programs along these lines, although it is still necessary to give a more ambitious approach, where local and global adopt a glocal perspective, because although it has been perceived that the students meet basic level socio-environmental problems that happen in the world, and consequently, their local dimensions are related to other global dimensions, it is detected that the local-global relationship is a pending task in which further work. And is that, as stated De Paz (2004), both terms are part of the same reality and therefore it is necessary to address them in an integrated perspective, by referring to the phrase we've all ever heard we must think globally act locally . 
necesario abordarlos desde una perspectiva integrada, remitiéndonos a la frase que todos hemos escuchado alguna vez "hay que actuar localmente pensando globalmente".

$Y$ es que las problemáticas socio-ambientales locales afectan al planeta donde se habita y que aunque individualmente se pueda hacer poco, o parezca que se pueda hacer poco, cada gesto tiene un significado inmenso. Una idea que se ha visto expresada a través de la idea de que

“cada granito de arena forma parte de la montaña"

En cuanto al sentimiento de pertenecer a una comunidad global, que el alumnado se sienta parte de una ciudadanía planetaria, aunque no entienda el concepto a grandes rasgos, y considere que se debe de actuar desde la solidaridad, es un paso importante para poder comenzar a trabajar desde la escuela.

En cuanto al análisis de progresión de conocimiento, en todas las categorías estudiadas, aunque con matices, se ha detectado que el alumnado se encuentra en lo que hemos denominado cosmovisión analítica, es decir, el alumnado posee conocimientos e incluso es capaz de poner en marcha procedimientos en torno a una mejora significativa de los temas englobados dentro de las categorías estudiadas, sin embargo hay que seguir trabajando para que se adquiera también un mayor grado de sensibilización y concienciación con las problemáticas que nos rodean con el fin de alcanzar lo que hemos denominado aproximación a una cosmovisión sistémica o pensamiento deseable..

Para finalizar queremos incidir en que es evidente que estos programas educativos se muestran como instrumentos de gran valor didáctico y pedagógico para desarrollar una educación ciudadana participativa al favorecer el aprendizaje de aquellos elementos o aspectos de la ciudadanía más vinculados con el compromiso y con la acción de transformación social.
And is that local socio-environmental issues affecting the planet where one lives and although little can be done individually, or appear to be doing little, every gesture has immense significance. One idea that has been expressed through the idea that

'every bit a part of the mountain'

As for the feeling of belonging to a global community, the students part of a planetary citizenship feel, but do not understand the concept broadly and consider to be acting out of solidarity, is an important step to start work from school.

For analysis of progression of knowledge in all categories studied, although with nuances, has detected that the student is in what we have called analytical worldview, ie, the student has knowledge and is even able to launch procedures to deal with a significant improvement in the subjects encompassed within the categories studied, however we must continue working to also acquire greater sensitivity and awareness to the problems that surround us to achieve what we have called approach to a systemic worldview or thought desirable.

We influence is evident that these educational programs are shown as extremely didactic and pedagogical value to develop a participatory citizenship education to encourage the learning of those elements or aspects of the citizenship linked with a commitment to finish with action social transformation. 
Anexo 1

Cuestionario investigación "Educación ambiental y educación para la ciudadanía desde una perspectiva planetaria. Estudio de experiencias educativas en Andalucía".

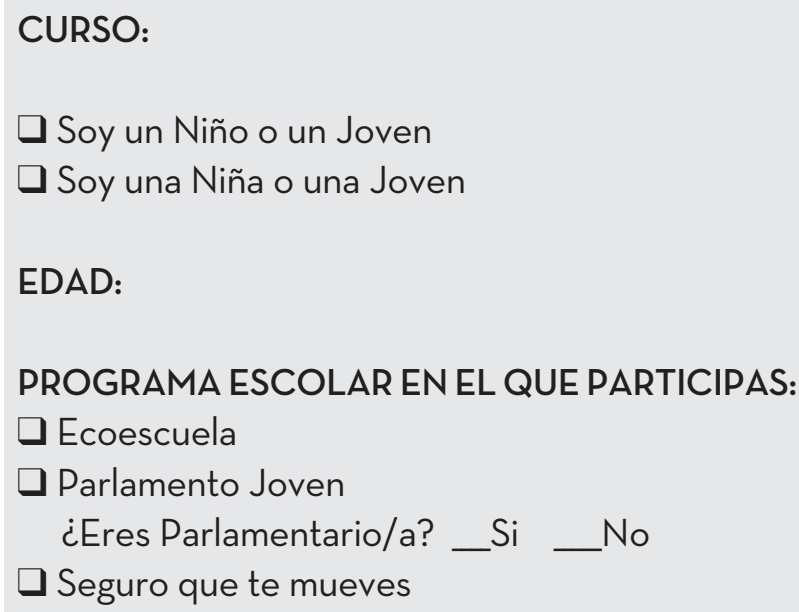

Este programa no es sólo importante para tu centro y para ti, sino también para todo aquello que te rodea. Con este cuestionario nos ayudaras a conocer más a fondo el programa y a saber qué cosas son importantes para ti en relación al medio ambiente, la ciudadanía y la participación.

1. El programa escolar en el que participas es importante para ti y para tu escuela:

a. Cuéntanos en qué ha consistido el programa (Ecoescuela, Parlamento Joven, Seguro que te mueves) durante el curso anterior:

b. ¿Qué crees que has aprendido con ese programa (Ecoescuela, Parlamento Joven, Seguro que te mueves)?

\section{Annex 1}

Research Questions of Environmental education and citizenship education from a planetary perspective. Study of educational experiences in Andalusia .

\section{COURSE:}

I'm a boy

I'm a girl

AGE:

\section{SCHOOL PROGRAMME TO PARTICIPATE: \\ $\square$ Eco-School \\ $\square$ Youth Parliament \\ Are you parliamentary? _Y Yes _No \\ $\square$ Sure you move}

This program is not only important for your heart and for you, but for everything that surrounds you. With this questionnaire you will help us to learn more about the program and know what things are important to you in relation to the environment, citizenship and participation.

1. The school program in which you participate is important for you and your school:

a. Tell us what has been to the (Eco-School, Youth Parliament, Sure you move) program during the previous year:

b. What do you think you've learned with the program (Eco-School, Youth Parliament, Sure you move)? 
c. De lo que has aprendido en el programa (Ecoescuela, Parlamento Joven, Seguro que te mueves) ¿Qué está siendo útil en tu vida diaria?

2. La escasez de agua en Andalucía es por primera vez en los últimos diez años uno de los problemas ambientales más importantes que tienen los andaluces. Para solucionar este problema, muchos pueblecitos se han puesto de acuerdo y han tomado medidas como cortar el agua desde las 8 de la tarde hasta las 8 de la mañana, sin embargo, otros pueblecitos se niegan a esta medida sin preocuparles este problema. No podemos olvidar que el agua es un recurso básico del que dependen no sólo los seres humanos, sino también plantas y animales.

¿Cómo crees que afectaría la falta de agua al lugar donde tú vives?

3. ¿Crees que este problema de falta de agua afectaría sólo a tu localidad, o es un problema que afecta a toda la Tierra?, ¿Por qué?

4. Si ocurriera ¿Cómo relacionarías la falta de agua en donde tú vives con la falta de agua en toda la Tierra?

5. ¿Qué propondrías tú para solucionar la falta de agua en tu pueblo? c. From what l've learned in the program (EcoSchool, Youth Parliament, Sure you move). What is still useful in your daily life?

2. Water scarcity in Andalusia is the first time in the last ten years one of the most important environmental problems of the Andalusians. To solve this problem, many villages have agreed and have taken steps like cutting the water from 8 $\mathrm{pm}$ to $8 \mathrm{am}$, however, other villages refuse to measure without worrying this problem. We can not forget that water is a basic resource on which they depend not only human beings but also plants and animals.

How do you think the lack of water affect the place where you live?

3. Do you think this problem of water shortage affects only your location, or is a problem that affects the entire Earth ?, Why?

4. If you happen, how would you relate the lack of water where you live with the lack of water throughout the Earth?

5. What would you propose you to solve the lack of water in your town? 
6.¿Y para solucionar la falta de agua en la Tierra?

7. ¿De quién crees que son responsabilidad los problemas medio ambientales, como por ejemplo el del uso del agua? ¿De los gobiernos? ¿De las empresas que administran el uso del agua? ¿De todas las personas? ¿Por qué?

8. Cuéntanos que cosas haces tú y como participas para mejorar los problemas del lugar en el que vives (tu ciudad, tu pueblo, tu barrio,...)
6. And to solve the lack of water on Earth?

7. Who do you think are the responsibility of environmental problems, such as water use? How governments? How companies manage water use? Is a problem of all the people? Why?

8. Tell us what things you do you and participate to improve the problems of where you live (your city, your town, your neighborhood,...) 


\section{Referencias bibliográficas / References}

Banks, J. A. (1997). Educating Citizens in a Multicultural Society. New York: Teachers

Columbia University.

Bárcena, F. (1997). El oficio de la ciudadanía. Barcelona: Paidós

Bartolomé, M. (2000). La construcción de la identidad en contextos multiculturales. Madrid: Ministerio de Educación, Cultura y Deporte.

Beck, U. (2006). Cosmopolitan Vision. Cambridge: PolityPress.

Bell, G.H. (1991). European citizenship: 1992 and beyond. Westminster studies in education, no 4.

Boff, L. (1995). Nueva era: la civilización planetaria: desafíos a la sociedad y al cristianismo. Navarra: Verbo Divino.

Bonal, X; Tarabino-Castellani, A., \& Verger, A. (2007). Globalización y educación. Textos fundamentales. Buenos Aires: Miño y Dávila.

Boni, A. (2011). Educación para la ciudadanía global. Significados y espacios para un cosmopolitismo transformador. Revista Española de Educación Comparada, 17, 65-86.

Boni, A;Hofmann, A., \& Sow, J. (2012). Educando para la ciudadanía global: una experiencia de investigación cooperativa entre docentes y profesionales de las ONGD. ESE: Estudios sobre educación, 23, 63-81.

Bourn, D. (2008). Developmenteducation: debates and dialogue. London: University of London, Institute of Education.

Cabrera, F. (2002). Hacia una nueva concepción de la ciudadanía en una sociedad multicultural. En M. Bartolomé (Coord.). Identidad y Ciudadanía. Un reto a la educación intercultural (79-204). Madrid: Narcea.

Camps, V. (2000). Los valores de la educación. Madrid: Anaya.

Carneiro, R. (1996). La relativización de la educación y las comunidades humanas: una visión de la escuela socializadora del siglo XXI. In UNESCO (Ed.). La educación encierra un tesoro, Informe UNESCO de la Comisión Internacional sobre educación para el siglo XXI. Madrid: Santillana/UNESCO.

Carneiro, R. (1999). Educación para la ciudadanía y las ciudades educadoras. Conferencia inaugural del Congreso Proyecto educativo de Ciudad. Educación para la ciudadanía. Barcelona: Mimeo.

Cortina, A., (1996). Educar moralmente ¿Qué valores para qué sociedad? In A. Cortina et al. Un Mundo de valores (pp. 27-38). Valencia: Generalitat Valenciana.

Cortina, A. (1990). Ética sin moral. Madrid: Tecnos.

Cortina, A. (2003). Hacia un concepto de ciudadanía para el siglo XXI. Misión Joven, 314, 17-24.

Crang, P. (2005). Local-Global. En P. Cloke; P. Crang y M. Goodwing (Eds.). Introducing Human Geographies(2434). Italy: HodderArnold.

De Paz, M. A. (2004). Global vs local. Un instrumento de integración: la inteligencia territorial. En VVAA. Lecturas de Economía Aplicada, Homenaje al profesor Antonio Rallo (85-100). Sevilla: Edición digital @ tres, S.L.

De Paz, D. (2007). Escuelas y educación para la ciudadanía global. Barcelona: Intermon Oxfam.

Denzin, N. K. (1970). SociologicalMethods: a Source Book. Chicago: Aldine Publishing Company.

Dias, G. M., \& Bonotto, D. M. B. (2012). As dimensões local e global nos entendimentos e práticas de professores participantes de um curso de formação continuada emeducação ambiental. Revista Electrónica de Enseñanza de las Ciencias, 11, 145-163.

Dobson, A. (2001). Ciudadanía ecológica: ¿̇una influencia desestabilizadora?, Isegoría, 24, 167-187.

Dobson, A. (2005). Ciudadanía ecológica, Isegoría, 32, 47-62.

Eurydice (2005). La educación para la ciudadanía en el contexto escolar europeo. Bruselas-Madrid: EuridyceCide.

Eurydice (2012). Citizenship Education in Europa. Bruselas: Education, Audiovisual and Culture Executive Agency.

Ferrete, C. (2011). Ciudadanía sin límites: el trasfondo de la gobernanza global. Quaderns de filosofia i ciència, 41, 89-98. 
Gadotti, M. et al (2003). Perspectivas actuales de la educación. México: Siglo XXI.

García Díaz, J. E. (1998). Hacia una teoría alternativa sobre los contenidos escolares.Sevilla: Díada.

García Pérez, F.F. (2000). Un modelo didáctico alternativo para transformar la educación: el modelo de investigación en la escuela. Scripta Nova, no 66. Retrieved from http://www.ub.edu/geocrit/sn-64.htm

García Pérez, F.F., \& De Alba, N. (2008). ¿Puede la escuela del siglo XXI educar a los ciudadanos y ciudadanas del siglo XXI?, Actas X Coloquio Internacional de Geocrítica. Diez años de cambios en el mundo, en la geografía y en las ciencias sociales, 1999-2008. Barcelona: Universidad de Barcelona.

Giroux, H. (1993). La escuela y la lucha por la ciudadanía. Pedagogía crítica de la época moderna. México: Siglo XXI.

Gutiérrez Pérez, F., \& Prado, C. (1995). Ecopedagogía: Ciudadanía planetaria. Costa Rica: Editorial Heredia.

Gutiérrez Pérez, F. (2003). Ciudadanía planetaria. En J. Martínez Bonafé (Coord.). Ciudadanía, poder y educación (133-155). Barcelona: Graó.

Intered (2011). Educación para el desarrollo y la ciudadanía global. Guía para su integración en los centros educativos. Madrid: Intered.

Inglehart, R. (1996). Chagements des comportaments civiques entre generations: le role de léducation et de la securité économique dans le déclin du respect del a autiricé au sein de la societé industrielle. Perpectives, 4, 697-707

Intermon-Oxfam (2005). Educar para una ciudadanía global. Propuesta educativa 2005-2006: Pobreza cero. Barcelona: Intermon Oxfam.

Intermon-Oxfam (2008). Pistas para cambiar la escuela. Barcelona: Intermon Oxfam Editorial.

Kymlicka, W. (1995). Ciudadanía Intercultural. Barcelona: Paidós

Majó, J. (2002). Ciudadanía social. En Imbernón, F. (Coord.). Cinco ciudadanías para la nueva educación. Barcelona: Graó.

Márquez Ramírez, I. O. (2010). Educación y escuela: configuraciones como clave en la formación ciudadana. Entelequia, 12, 91-104.

Martínez Martín, M. (2011). Educación, valores y democracia. Revista de Educación,no Extraordinario 1, 15-19.

Martínez Bonafé, J. (2003). Ciudadanía, Poder y Educación. Barcelona: Graó.

Mayer, M. (2002). Ciudadanos del barrio y del planeta. En F. Imbernón (Coord). Cinco ciudadanías para una nueva educación (83-104). Barcelona: Graó.

Mayordomo, A. (1998). El aprendizaje cívico. Barcelona: Ariel

Merryfield, M., Jarchow, E., \& Pickert, S. (Eds.). (1997). Preparing teachers to teach global perspectives: A handbook for teacher educators. California: Corwin Press.

Ministerio de Asuntos Exteriores y de Cooperación (2009). Plan Director de la Cooperación Española 20052008. Madrid: Gráficas Hervi.

Ministerio de Asuntos Exteriores y de Cooperación (2009). Plan Director de la Cooperación Española 20092012. Madrid: Gráficas Hervi.

Moreno Fernández, O; Moreno Crespo, P. A., \& Martín Bermúdez, N. (2011). Educación popular, educación de adultos y educación para el desarrollo: motores para el cambio social. Actas del 30 Congreso Internacional Ibero-Americano de Pedagogía Social. Brasil: SIPS.

Moreno Fernández, O; Moreno Crespo, P.A., \& Martín, N. (2011). Educación popular, educación de adultos y educación para el desarrollo: motores para el cambio social. Actas del 30 Congreso Internacional IberoAmericano de Pedagogía Social, Canoas (Brasil).

Moreno Fernández, O., \& García Pérez, F.F. (2013). Educar para la participación desde una perspectiva planetaria. Íber: Didáctica de las Ciencias Sociales, Geografía e Historia, 74, 9-16.

Moreno Fernández y Bonotto, D. M. B. (2014). Educar para una ciudadanía planetaria: una perspectiva necesaria desde la que entender la Educación Ambiental. Global Education Magazine, 8, 40-43.

Naciones Unidas (1945). Carta de las Naciones Unidas. Firmada el 26 de junio de 1945. Entrada en vigor el 24 de octubre de 1945, de conformidad con el art. 110. Estados Unidos: San Francisco.

[ 260 ] OLGA MORENO FERNÁNDEZ

SIPS - PEDAGOGIA SOCIAL. REVISTA INTERUNIVERSITARIA [1139-1723 (2015) 26, 229-261] TERCERA ÉPOCA 
Naval, C. (2001). La educación (moral y cívica) en una sociedad globalizada. ESE:Estudios sobre Educación, 1, 21-36.

Novo, M., \& Murga, Ma A. (2010). Educación ambiental y ciudadanía planetaria. Rev. Eureka, 7, No Extraordinario, 179-186.

Nussbaum, M. (1999). Patriotismo y cosmopolitismo. In M. Nussbaum (Ed.). Los límites del patriotismo. Identidad, Pertenencia y "Ciudadanía Mundial» (13-29). Barcelona: Paidós

Olu, M. S. (1997). Models of multiculturalism: implications for the twenty-firt century leaders. European Journal of Intercultural Studies, 8 (3), 231-256.

Oriens (2011). Seguro que te mueves. Sevilla: Diputación de Sevilla.

Santos, M. (2002). Por umaoutraglobalização: do pensamento único a consciência universal. Rio de Janeiro: Record.

Osler, A. (1998). European Citizenship and Study Abroad: student teachers' experiences and identities. Cambridge Journal of Education, 28(1), 77-96.

Osler, A. (ED.) (2000). Citizenship and Democracy in school. Staffordshire: Trentham Books.

Spencer, S. Y Klug, F. (1998). Multicultural Teaching. New York: Trebtham Books.

Pasquino, G. (2001). Ciudadanía mundial. Psicología Política, 23, 59-75.

Unicef (2005).Educación para la ciudadanía. Aportaciones a la propuesta para el debate del Ministerio de Educación y Ciencia "Una educación de calidad para todos y entre todos". UNICEF: Comité Español.

Wilbanks, T. J., \& Kates, R. W. (1999). Global change in local place: how scale

matters. Climatic Change, vol. 1, 43, 601-628.

Van Steenbergen, B. (1994). Towards a Global Ecological Citizen. In B. Van Steenbergen (Ed.). The Condition of Citizenship (141-152). London: Sage.

\section{CÓMO CITAR ESTE ARTÍCULO / HOW TO CITE THE ARTICLE}

Moreno Fernández, O., (2015). Educación y Ciudadanía Planetaria.

Concepciones del alumnado participante en programas educativos andaluces. Pedagogía Social. Revista Interuniversitaria, 26 229-261. DOI:10.7179/PSRI_2015.26.09

Fecha de recepción del artículo / received date: 6.VI.2014

Fecha de revisión del artículo / reviewed date: 9.VI.2014

Fecha de aceptación final / accepted date: 12.III.2015

\section{DIRECCIÓN DE LAS AUTORAS/ AUTHORS' ADDRESS}

Olga Moreno Fernández . Universidad de Sevilla. Facultad de Ciencias de la Educación. Departamento de Didáctica de las Ciencias Experimentales y Sociales. C/ Pirotecnia s/n Despacho 4.93, 41013. Sevilla. Dirección de correo/e-mail: omoreno@us.es

\section{PERFIL ACADÉMICO / ACADEMIC PROFILE}

Olga Moreno Fernández. Profesora del Departamento de Didáctica de las Ciencias Experimentales y Sociales de la Universidad de Sevilla. Doctora en Estudios Medioambientales, Máster Interuniversitario en Educación Ambiental, Licenciada en Humanidades, y Diplomada en Magisterio. Ha realizado trabajos de investigación sobre las ideas previas del alumnado en cuánto a problemas medioambientales, la escuela inclusiva y las nuevas tecnologías, la enseñanza en valores y la participación ciudadana planetaria, tema en el que actualmente trabaja con la investigación “Educación Ambiental y Educación para la ciudadanía desde una perspectiva planetaria". 
